Article

\title{
Pt-Promoted Tungsten Carbide Nanostructures on Mesoporous Pinewood-Derived Activated Carbon for Catalytic Oxidation of Formaldehyde at Low Temperatures
}

\author{
Qiangu Yan ${ }^{1}\left[\right.$ and Zhiyong Cai ${ }^{2, *}$ \\ 1 Ligwood LLC, Madison, WI 53705, USA; yanqiangu@gmail.com \\ 2 Forest Products Laboratory, One Gifford Pinchot Drive, Madison, WI 53726-2398, USA \\ * Correspondence: zhiyong.cai@usda.gov
}

Received: 15 June 2020; Accepted: 5 August 2020; Published: 7 August 2020

check for updates

\begin{abstract}
Tungsten carbide (WC) nanostructures were prepared by carbothermal reduction (CR) of tungsten-impregnated pinewood-derived activated carbon (AC) at $1000{ }^{\circ} \mathrm{C}$ under an inert atmosphere. Brunauer-Emmet-Teller (BET) surface area, pore structures of the AC, and catalyst samples were evaluated by $\mathrm{N}_{2}$ adsorption-desorption experiments. The structures of the catalysts were characterized using X-ray powder diffraction (XRD). The morphologies and particle structures of the synthesized WC nanoparticles were investigated by field emission scanning electron microscopy (FESEM) and high-resolution transmission electron microscopy (HRTEM). The WC/AC material was used as support of the platinum catalysts for catalytic oxidation of formaldehyde (HCHO) from interior sources. $\mathrm{Pt}-\mathrm{WC} / \mathrm{AC}$ catalysts with different platinum loadings were assessed for the catalytic oxidation of $\mathrm{HCHO}$ at low temperature. The catalytic performance was found to be significantly influenced by reaction temperature, initial formaldehyde concentration, relative humidity, and space velocity. The testing results demonstrated that $\mathrm{HCHO}$ can be totally oxidized by the $1 \mathrm{wt} \% \mathrm{Pt}-\mathrm{WC} / \mathrm{AC}$ catalyst in the gas hourly space velocity $(\mathrm{GHSV})=50,000 \mathrm{~h}^{-1}$ at $30^{\circ} \mathrm{C}$ with a relative humidity $(\mathrm{RH})$ of $40 \%$.
\end{abstract}

Keywords: catalytic oxidation; $\mathrm{HCHO}$ removal; $\mathrm{Pt}-\mathrm{WC} /$ wood-char catalyst; tungsten carbide nanostructures

\section{Introduction}

Formaldehyde $(\mathrm{HCHO})$ is a colorless, flammable, strong-smelling organic compound $[1,2]$ and is an important chemical feedstock as a precursor to many widely used materials and chemical compounds in manufactural industry [1,2]. Large quantities of formaldehyde (over millions of tons) are used each year in the production of household supplies, such as shampoo, lipstick, toothpaste, vaccines, disinfectants, paper product coatings, permanent-press clothing, and liquid coatings [1]. Formaldehyde is mainly used in the production of industrial resins [3], which are widely used in various materials for furniture manufacturing and the construction industry, including insulation materials, glues and adhesives, particleboards, plywoods, and fiberboards [4]. Due to its high volatility, significant amounts of formaldehyde are released into the air from furniture and building materials, with the pressed-wood products (particleboards, plywoods, and fiberboards) being the main sources of indoor air pollution [2,5]. HCHO is highly toxic to human beings and animals [1]. Long-term contact to formaldehyde, even at low levels of a few ppm, may cause people to suffer a variety of health problems such as stinging, coughing, hyperventilating, a sore throat, shortness of breath, headache, 
qualmishness, nasal tumors, eye and skin irritation, nasopharyngeal cancer, and even death $[1,4,6]$. Therefore, formaldehyde is one of the most toxic interior air contaminants [1].

Various techniques have been developed to remove $\mathrm{HCHO}$ from indoor air, including physical adsorption by porous adsorbent materials [7], chemical absorption [8], photocatalytic oxidation with ultraviolet (UV) irradiation [9], plasma degradation [10], and catalytic combustion [11]. However, these methods are restricted by limited adsorption capacity, require light sources or expensive plasma equipment with high energy consumption, etc. [12]. Researchers have recently paid more attention to complete catalytic oxidation to remove indoor $\mathrm{HCHO}$ pollution, thanks to its low reaction temperature and low energy consumption [13]. In this process, $\mathrm{HCHO}$ in the polluted air is catalytically oxidized to $\mathrm{CO}_{2}$ and $\mathrm{H}_{2} \mathrm{O}$ with the assistance of catalysts at room temperature. At ambient temperature, high activity catalysts are needed to completely convert the low concentration formaldehyde in indoor air.

Catalysts used in complete oxidation of $\mathrm{HCHO}$ at low temperature are classified into two groups: supported platinum-group metals (such as platinum, palladium, gold and silver) [14], and transitional metal oxides (such as $\mathrm{CuO}, \mathrm{MnO}_{2}$, and $\mathrm{TiO}_{2}$, etc.) [14]. Supported $\mathrm{Pt}, \mathrm{Pd}$ and $\mathrm{Au}$ catalysts exhibit superior catalytic performance for complete oxidation of $\mathrm{HCHO}$ at low temperature, compared to supported Ag catalysts and transitional metal oxide catalysts. Pt-based catalysts show the best catalytic performance for removal of $\mathrm{HCHO}$ at room temperature $[13,15]$. They demonstrate excellent catalytic activity and stability for HCHO removal from indoor air; however, their practical applications are limited due to the cost of noble metals $[13,16]$. Thus, it is necessary to develop catalysts that can efficiently oxidize $\mathrm{HCHO}$ in indoor air through a cost-effective approach. There are two strategies to prepare affordable $\mathrm{HCHO}$ oxidation catalysts: prepare noble metal-based catalysts with reduced $\mathrm{Pt}$ metal loading and develop non-noble metal catalysts. Researchers have made great efforts to explore transitional metal oxides as catalysts for the complete oxidation of $\mathrm{HCHO}$. $\mathrm{TiO}_{2}, \mathrm{Fe}_{2} \mathrm{O}_{3}$, $\mathrm{ZrO}_{2}, \mathrm{CoO}, \mathrm{CeO}_{2}, \mathrm{~V}_{2} \mathrm{O}_{5}, \mathrm{MnO}_{2}$, hydroxyapatite, and $\mathrm{H}-\mathrm{TiO}_{2} / \mathrm{H}-\mathrm{C}-\mathrm{TiO}_{2}$ are reported by different groups [13,14]; however, due to their limited catalytic activity and stability, development of affordable and high performance transitional metal oxide catalysts for $\mathrm{HCHO}$ removal at low temperature is still a challenge [13].

In the past decade, transition metal carbides, especially tungsten and molybdenum carbide, have been examined as catalysts for varieties of reactions [17]. These transitional metal carbides have demonstrated excellent activity, stability, and selectivity, comparable to the noble metal-based catalysts [18]. Tungsten carbide (WC) shows Pt-like catalytic activity in reactions, such as hydrocarbon reforming to syngas, water gas shift reaction, hydrogenation, desulfurization, $\mathrm{CO}_{2}$ reduction, hydrocarbon isomerization, and electric oxidation of methanol [19]. Transitional metal carbides can either be directly used as catalysts or serve as supporters/promoters to the Pt-group catalysts [17]. $\mathrm{Pt} / \mathrm{WC}$ catalysts were reported to double the activity for electrochemical oxidation of hydrogen, compared to a commercial $\mathrm{Pt} / \mathrm{C}$ catalyst at room temperature [20].

The catalytic performance for complete oxidation of $\mathrm{HCHO}$ is mainly influenced by catalyst structure and composition as well as operational process variables [21]. These catalyst factors include their preparation method, active metals and metal loading of the catalyst, and the catalyst support. In this study, carbon tungsten nanostructures were prepared by carbothermal reduction (CR) of tungsten-impregnated wood-char. WC/wood-char material was used as support of the platinum catalysts for complete oxidation of formaldehyde from interior sources. The physicochemical properties of the synthesized tungsten carbide nanoparticles were characterized by physical $\mathrm{N}_{2}$ adsorption, field emission scanning electron microscopy (FESEM), high-resolution transmission electron microscopy (HRTEM), and X-ray powder diffraction (XRD). The catalytic performance for complete oxidation of $\mathrm{HCHO}$ was examined under different process temperatures, formaldehyde concentrations, relative humidity, and velocity of the feeding gases. 


\section{Experimental}

\subsection{Wood-Derived Activated Carbon (AC) Preparation and Pretreatment}

The AC materials used in this work were prepared from loblolly pine wood chips by $\mathrm{CO}_{2}$ gasification process. For each $\mathrm{CO}_{2}$ gasification run, $100 \mathrm{~g}$ of pine wood chips (1-2 $\left.\mathrm{mm}\right)$ were loaded into a tubular reactor (2-inch O.D. 316 stainless steel). Argon $(100 \mathrm{~mL} / \mathrm{min})$ and $\mathrm{CO}_{2}(400 \mathrm{~mL} / \mathrm{min})$ were first introduced into the reactor for $30 \mathrm{~min}$. The reactor was then heated at a rate of $20{ }^{\circ} \mathrm{C} / \mathrm{min}$ to $800{ }^{\circ} \mathrm{C}$ and gasified at $800{ }^{\circ} \mathrm{C}$ for $0.5 \mathrm{~h}$. The solid char yield was around $18-20 \%$. The prepared wood char was sieved into the particle size range of $0.10-0.20 \mathrm{~mm}$. To remove soluble inorganic ions and

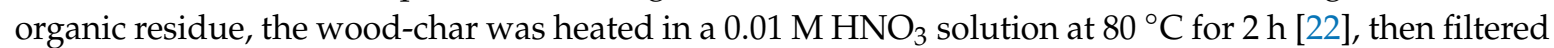
and washed with hot deionized (DI) water three times. The washed pine wood char was then dried at $105^{\circ} \mathrm{C}$ for $12 \mathrm{~h}$. The treated wood char was denoted as AC and used as the catalyst support.

\subsection{Preparation of AC Supported Tungsten Carbide}

WC/AC was synthesized through a carbothermal reduction process [22]. WC/AC precursor is prepared using an incipient wetness impregnation method. A total of $32.4 \mathrm{~g}$ of ammonium metatungstate hydrate $\left(\left(\mathrm{NH}_{4}\right)_{6} \mathrm{H}_{2} \mathrm{~W}_{12} \mathrm{O}_{40} \times \mathrm{xH}_{2} \mathrm{O}\right.$ (Sigma-Aldrich, St. Louis, MO, USA) is dissolved in $50 \mathrm{~mL}$ DI water, and the solution is heated up to $80^{\circ} \mathrm{C}$ and stirred for $30 \mathrm{~min}$. The ammonium metatungstate solution is added slowly to the AC. The final mixture is stirred for $1 \mathrm{~h}$, the mixture was kept in a hood at room temperature for $24 \mathrm{~h}$, then dried in an oven at $110{ }^{\circ} \mathrm{C}$ for $24 \mathrm{~h}$. The dried W-AC precursors were loaded into a 2-inch tubular reactor. The reactor was first purged with an argon $(99.99 \%)$ flow $(100 \mathrm{~mL} / \mathrm{min})$ for $0.5 \mathrm{~h}$. The reactor was then heated to $1000{ }^{\circ} \mathrm{C}$ at a ramp rate of $3{ }^{\circ} \mathrm{C} / \mathrm{min}$ under argon atmosphere and kept at $1000^{\circ} \mathrm{C}$ for $2 \mathrm{~h}$. The yield of the solid product was $\sim 60.5 \%$, and the carbonized material was denoted as WC/AC.

\subsection{Preparation of Pt-WC/AC Catalysts}

The WC/AC supported Pt (0.1-2.0 wt\%) catalysts were prepared by the borohydride reduction method [23]. $\mathrm{H}_{2} \mathrm{PtCl}_{6}$ was first dissolved in an appropriate amount of DI water. WC/AC was then dispersed in $\mathrm{H}_{2} \mathrm{PtCl}_{6}$ solution with continuing stirring. The mixture of $\mathrm{Pt}$ salt and the WC/AC were reduced by using the required amount of sodium borohydride solution. The prepared Pt-WC/AC sample was washed with DI water then dried at $80^{\circ} \mathrm{C}$ in an oven for $24 \mathrm{~h}$. The bulk density of the prepared catalyst is $\sim 0.83 \mathrm{~g} / \mathrm{mL}$.

\subsection{Analysis and Characterization of Samples}

The elemental compositions $(\mathrm{C}, \mathrm{H}$, and $\mathrm{N}$ ) of the wood-char and catalyst samples were evaluated using an elemental analyzer (Perkin Elmer PE2400 series II, PerkinElmer, Billerica, MA, USA). Each run was repeated at least three times. Metal elemental analysis was conducted on an ICP Optical Emission Spectrometry system (Agilent 5800 ICP-OES Spectrometer, Santa Clara, CA, USA). The Pt/AC and $\mathrm{Pt}-\mathrm{WC} / \mathrm{AC}$ samples were first combusted in air, and the ash was collected and dissolved with an acid solution. The metal dissolved solution was then used for ICP-OES analysis.

Brunauer-Emmet-Teller (BET) surface area and pore structures of the wood char, WC/AC, Pt/AC and Pt-WC/AC samples were evaluated by $\mathrm{N}_{2}$ physisorption experiments (Tristar II, Micromeritics, Norcross, GA, USA). Approximately $100 \mathrm{mg}$ of solid samples were used for each analysis. These samples were first degassed at $300{ }^{\circ} \mathrm{C}$ for $12 \mathrm{~h}$. The BET surface area of the samples was obtained from $\mathrm{N}_{2}$ adsorption isotherms, and pore size distribution was obtained by the Dollimore-Heal (DH) theory. The total pore volume was estimated to be the liquid volume of nitrogen at a relative pressure of about 0.99 . The average pore diameter was estimated from the surface area and total pore volume.

The FTIR spectra of raw wood char and nitric acid rinsed wood char samples were recorded with an ATR-FTIR spectrometer (Thermo Scientific, Nicolet iZ10, Thermo Fisher, Waltham, MA, USA) at a resolution of $4 \mathrm{~cm}^{-1}$ for 64 scans in 500 to $4000 \mathrm{~cm}^{-1}$ range. 
Pt dispersion measurements were performed at room temperature by $\mathrm{CO}$ pulse chemisorption experiments using a micromeritics AutoChem II 2920 Chemisorption Analyzer (Micromeritics, Norcross, GA, USA) equipped with an on-line residue gas analyzer (RGA). Prior to measurements, $100 \mathrm{mg}$ of the sample was reduced in a flow of hydrogen-argon mixture $\left(4.7 \% \mathrm{H}_{2}, 50 \mathrm{~mL} / \mathrm{min}\right)$ at $300{ }^{\circ} \mathrm{C}$ for $2 \mathrm{~h}$ and purged with high purity argon $(50 \mathrm{~mL} / \mathrm{min})$ for $1 \mathrm{~h}$ at the same temperature. CO chemisorption was performed by pulsing $\mathrm{CO}$ (using $5.1 \% \mathrm{CO}$ in argon) at $30^{\circ} \mathrm{C}$. Saturation of $\mathrm{CO}$ chemisorption was reached when three consecutive $\mathrm{CO}$ peaks showed the same intensity. The dispersion of $\mathrm{Pt}$ was calculated from CO chemisorption (assuming Pt/CO $=1 / 1$ ) using the equation of $\mathrm{D}_{\mathrm{Pt}}=\mathrm{N}_{\mathrm{ads}} / \mathrm{N}_{\mathrm{t}}$, where $\mathrm{N}_{\mathrm{ads}}$ is the total number of $\mathrm{CO}$ molecules that were irreversibly chemisorbed over Pt catalyst, and $\mathrm{Nt}$ is the total number of $\mathrm{Pt}$ atoms in the test catalyst.

$\mathrm{X}$-ray powder diffraction (XRD) data of the WC/AC, Pt/AC and Pt-WC/AC samples were collected using a Rigaku Ultima III X-ray Diffraction System [22]. The average size of tungsten carbide particles was calculated using the Scherrer equation [22].

The morphologies of the WC/AC, and Pt-WC/AC samples were investigated using a field emission scanning electron microscope (FESEM, JEOL JSM-6500F). The particle size and structures of tungsten carbide in WC/AC and Pt-WC/AC was studied using high resolution transmission electron microscopy (HRTEM, JEOL, JEM-2100).

\subsection{Evaluation of Catalytic Performance}

The complete oxidation of $\mathrm{HCHO}$ over different catalysts was investigated over a tubular (o.d. $=0.25$ in., stainless steel) fixed bed reactor mounted in a split tubular furnace under atmospheric pressure. $0.2 \mathrm{~g}(\sim 0.24 \mathrm{~mL})$ of catalyst sample was loaded into the reactor for each run. The catalysts were first loaded into the reactor and a thermocouple was inserted in the middle of the catalyst bed. Before catalytic conversion, the fresh catalyst was reduced in a $5 \% \mathrm{H}_{2}$ in argon flow at $350{ }^{\circ} \mathrm{C}$ for $2 \mathrm{~h}$ under atmospheric pressure, followed by reduction in temperature to room temperature. The catalytic performance of each catalyst was evaluated at temperatures ranging from room temperature to $50{ }^{\circ} \mathrm{C}$. $\mathrm{HCHO}$ in gas phase was generated by passing an Ar- $\mathrm{O}_{2}\left(20 \% \mathrm{O}_{2}\right)$ flow through an $\mathrm{HCHO}$ solution in an incubator. The total flow rate was fixed at $200 \mathrm{~mL} / \mathrm{min}$. The influence of moisture on the catalytic performance of $1.0 \mathrm{wt} \% \mathrm{Pt}-\mathrm{WC} / \mathrm{AC}$ catalyst for complete oxidation of $\mathrm{HCHO}$ was investigated at $3{ }^{\circ} \mathrm{C}$, with RH levels of $0 \%, 20 \%, 40 \%$, and $60 \%$; HCHO initial concentration of $200 \mathrm{ppm}$; and GHSV of $50,000 \mathrm{~h}^{-1}$. To study the effect of GHSVs on catalyst performance at room temperature, different amounts $(0.2 \mathrm{~g}, 0.1 \mathrm{~g}$ and $0.05 \mathrm{~g})$ of catalysts were used to control GHSV of 50,000 $\mathrm{h}^{-1}, 100,000 \mathrm{~h}^{-1}$, and 200,000 $\mathrm{h}^{-1}$, with an initial HCHO concentration of $100 \mathrm{ppm}$ using feed gas with $50 \% \mathrm{RH}$.

Products and reactants analysis was conducted using an on-line gas chromatograph equipped with a thermal conductivity detector (TCD) and a flame ionization detector (FID) (Shimadzu GC-2014-C). A Polyarc reactor (a Ni catalyst convertor) was installed to methanate carbon dioxide before the FID detector. $\mathrm{CO}_{2}$ was the only product detected in the outlet flow; no $\mathrm{CO}$ or other products were observed. $\mathrm{HCHO}$ was completely oxidized to carbon dioxide and water $\left(\mathrm{HCHO}+\mathrm{O}_{2} \rightarrow \mathrm{CO}_{2}+\mathrm{H}_{2} \mathrm{O}\right)$. The $\mathrm{HCHO}$ conversion rate is calculated as follows: $[\mathrm{HCHO}]_{\text {converted }}=[\mathrm{HCHO}]_{\text {inlet }}-[\mathrm{HCHO}]_{\text {outlet }}=$ $\left[\mathrm{CO}_{2}\right]_{\text {produced }}=\left[\mathrm{CO}_{2}\right]_{\text {outlet }}-\left[\mathrm{CO}_{2}\right]_{\text {inlet }}$, where $\left[\mathrm{CO}_{2}\right]_{\text {inlet }}=0$. Therefore, the HCHO conversion rate can be calculated as $\left[\mathrm{CO}_{2}\right]_{\text {outlet }} /[\mathrm{HCHO}]_{\text {inlet }}$. A calibrated curve was made by measuring gas samples with different $\mathrm{CO}_{2}$ concentrations. The converted $\mathrm{HCHO}$ was obtained through the calibrated $\mathrm{CO}_{2}$ curve. $\mathrm{HCHO}$ conversion rate was calculated by the equation:

$$
\mathrm{HCHO} \text { conversion }(\%)=\frac{[\mathrm{HCHO}]_{\text {inlet }}-[\mathrm{HCHO}]_{\text {outlet }}}{[\mathrm{HCHO}]_{\text {inlet }}} \times 100 \%=\frac{\left[\mathrm{CO}_{2}\right]_{\text {outlet }}}{[\mathrm{HCHO}]_{\text {inlet }}} \times 100 \%
$$

where $[\mathrm{HCHO}]_{\text {inlet }}$ and $\left[\mathrm{CO}_{2}\right]_{\text {outlet }}$ is the $\mathrm{HCHO}$ concentration in the inlet gas flow and the $\mathrm{CO}_{2}$ concentration in the outlet gas flow, respectively. 
In addition to the $\mathrm{HCHO}$ conversion rate, the turnover frequency (TOF) (i.e., number of molecules reacted per Pt surface atom) at room temperature was also used to evaluate the catalytic activities. The turnover frequency (TOF) was calculated as follows: TOF $=$ the amount of products $(\mathrm{mol}) /($ the amount of catalyst active sites $\times$ time $(\mathrm{min}))$. $\mathrm{HCHO}$ conversion rates in the first $30 \mathrm{~min}$ were for the calculation of TOF.

\section{Results and Discussion}

\subsection{Catalyst Analysis and Characterization}

FTIR and TPD Analysis of AC Samples

FTIR was used to identify the functional groups in wood-derived AC samples (Figure 1). The FTIR band at $3345 \mathrm{~cm}^{-1}$ on the raw and $\mathrm{HNO}_{3}$ solution rinsed activated carbon are attributed to the -OH stretch vibrations. Other FTIR bands are identified as follows: $\mathrm{C}=\mathrm{O}$ stretching vibrations $\left(1720 \mathrm{~cm}^{-1}\right)$, $\mathrm{C}=\mathrm{O}$ stretching $\left(1637 \mathrm{~cm}^{-1}\right), \mathrm{C}=\mathrm{O}$ and $\mathrm{C}-\mathrm{O}$ of carboxylic groups $\left(1395 \mathrm{~cm}^{-1}\right), \mathrm{O}-\mathrm{C}-\mathrm{O}$ vibrations $\left(1230 \mathrm{~cm}^{-1}\right), \mathrm{C}-\mathrm{O}$ vibrations $\left(1070 \mathrm{~cm}^{-1}\right)$, and $-\mathrm{OH}$ bending $\left(984 \mathrm{~cm}^{-1}\right)$. The intensities of the FTIR bands are significantly enhanced, indicating that the numbers of oxygen groups are increased after rinsing by the nitric acid solution. There is a new strong FTIR band at $3200 \mathrm{~cm}^{-1}$ for the acid-rinsed sample, which can be assigned to $\mathrm{O}-\mathrm{H}$ stretching of hydroxyl groups in carboxylic acid groups. This means nitric acid rinsing promotes the formation of oxygen-containing functional groups on the surface of ACs.

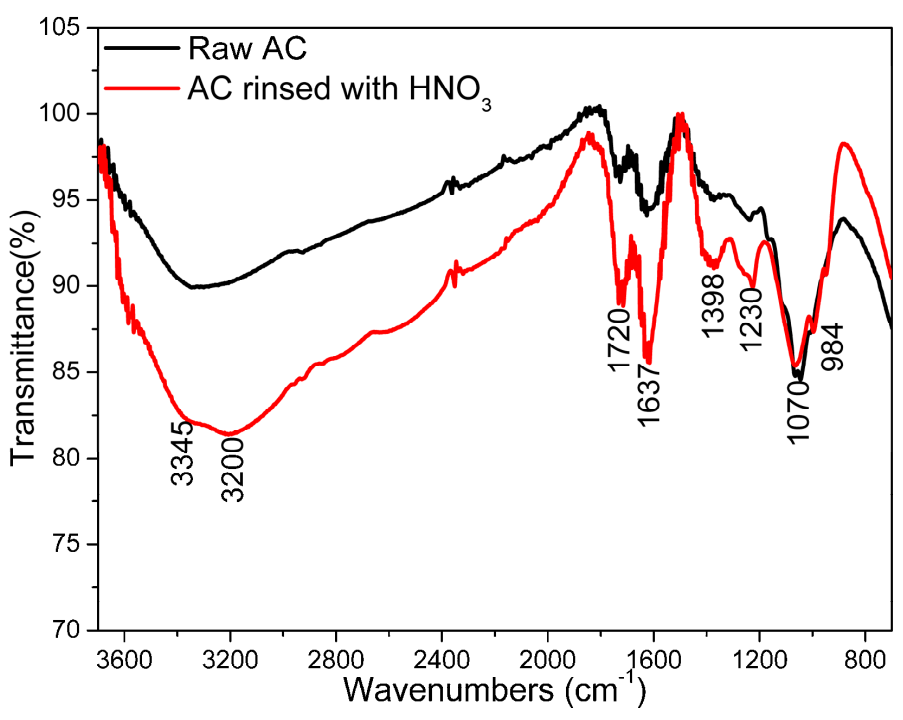

Figure 1. FTIR spectra of raw AC and nitric acid rinsed AC.

FTIR results showed oxygen containing functional groups in wood-derived AC samples. These oxygen containing groups will decompose to $\mathrm{CO}_{2}, \mathrm{H}_{2} \mathrm{O}$, and $\mathrm{CO}$ at elevated temperature. Temperature programmed desorption (TPD) analyses (Figure 2) were performed on raw AC and acid rinsed sample. The TPD results showed $\mathrm{H}_{2} \mathrm{O}$ and $\mathrm{CO}$ were the main desorption products of the raw $\mathrm{AC}$ (Figure 2a), while the oxygen groups were decomposed to $\mathrm{CO}_{2}, \mathrm{H}_{2} \mathrm{O}$, and $\mathrm{CO}$, and more gaseous products were generated from the rinsed sample during TPD process (Figure $2 b$ ). 


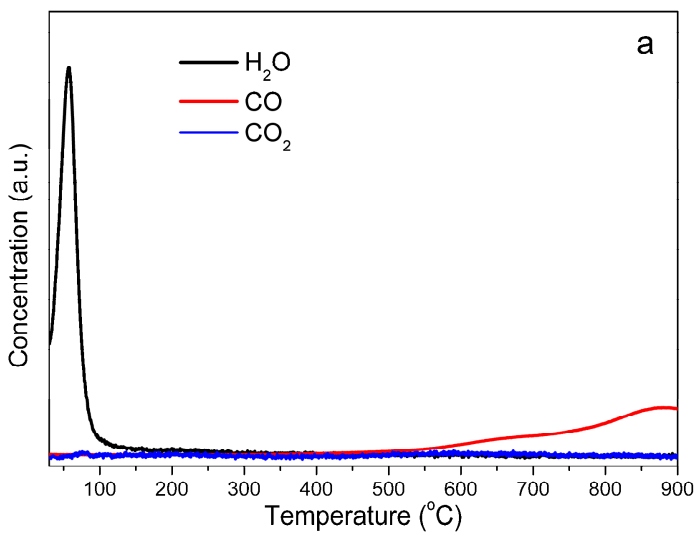

(a)

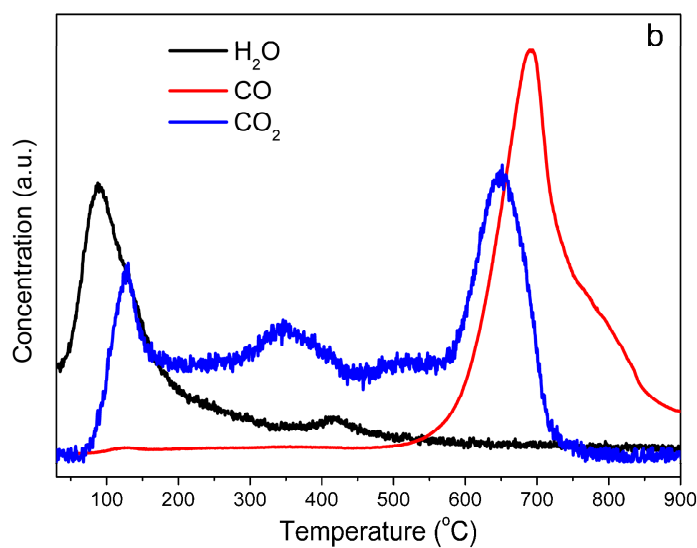

(b)

Figure 2. Temperature programmed desorption results of raw AC (a) and nitric acid rinsed AC (b) samples.

\subsection{Elemental Analysis}

Table 1 summarizes the $\mathrm{C}-\mathrm{H}-\mathrm{N}-\mathrm{O}, \mathrm{W}$, and Pt elemental analysis of raw $\mathrm{AC}$, acid treated $\mathrm{AC}$, $\mathrm{AC}-1000{ }^{\circ} \mathrm{C}, \mathrm{WC} / \mathrm{AC}, \mathrm{Pt} / \mathrm{AC}$, and Pt-WC/AC.

Table 1. Summary of weight percentages (wt \%) of $\mathrm{C}, \mathrm{H}, \mathrm{N}, \mathrm{O}, \mathrm{W}$ and $\mathrm{Pt}$ in raw wood-char, acid treated wood-char, $1000{ }^{\circ} \mathrm{C}$ carbonized wood-char, WC/AC, $1 \mathrm{wt} \% \mathrm{Pt}-\mathrm{WC} / \mathrm{AC}$, and $1 \mathrm{wt} \% \mathrm{Pt} / \mathrm{AC}$.

\begin{tabular}{ccccccc}
\hline Sample & $\begin{array}{c}\text { Raw } \\
\text { Wood-Char }\end{array}$ & $\begin{array}{c}\text { Acid Treated } \\
\text { Wood-Char }\end{array}$ & $\begin{array}{c}\text { Wood Char- } \\
\mathbf{1 0 0 0}{ }^{\circ} \mathbf{C}\end{array}$ & WC/AC & $\begin{array}{c}\mathbf{1} \text { wt\% } \\
\text { Pt-WC/AC }\end{array}$ & $\begin{array}{c}\mathbf{1} \text { wt\% } \\
\text { Pt/AC }\end{array}$ \\
\hline $\mathrm{C}(\mathrm{wt} \%)^{\mathrm{a}}$ & $88.9 \pm 0.7$ & $85.3 \pm 0.8$ & $92.5 \pm 0.5$ & $68.3 \pm 0.4$ & $67.6 \pm 0.3$ & $91.2 \pm 0.5$ \\
$\mathrm{H}(\mathrm{wt} \%)^{\mathrm{a}}$ & $1.8 \pm 0.2$ & $2.0 \pm 0.3$ & $0.5 \pm 0.1$ & $0.3 \pm 0.1$ & $0.4 \pm 0.05$ & $0.4 \pm 0.08$ \\
$\mathrm{O}(\mathrm{wt} \%)^{\mathrm{c}}$ & $9.2 \pm 0.5$ & $12.5 \pm 0.6$ & $7.0 \pm 0.5$ & $0.9 \pm 0.3$ & $0.9 \pm 0.3$ & $7.4 \pm 0.4$ \\
$\mathrm{~N}(\mathrm{wt} \%)^{\mathrm{a}}$ & $0.1 \pm 0.05$ & $0.1 \pm 0.03$ & - & - & - & - \\
$\mathrm{W}(\mathrm{wt} \%)^{\mathrm{b}}$ & - & - & - & $30.5 \pm 0.3$ & $30.1 \pm 0.7$ & - \\
$\mathrm{Pt}(\mathrm{wt} \%)^{\mathrm{b}}$ & - & - & - & - & $0.99 \pm 0.05$ & $1.02 \pm 0.03$ \\
\hline \multicolumn{7}{c}{${ }^{\mathrm{a}}$. Measured with an elemental analyzer; ${ }^{\mathrm{b}}$. Measured with ICP-OES; ${ }^{\mathrm{c}}$. Calculated by difference. }
\end{tabular}

Surface Area and Porosity of the AC Supported Catalysts

To explore changes in surface area and porosity properties caused by the activation process and loaded metal particles, the surface area and pore structures of the samples were measured by $\mathrm{N}_{2}$ physisorption method and the results were listed in Table 2. The BET surface areas for raw AC, acid treated $\mathrm{AC}, \mathrm{AC}-1000{ }^{\circ} \mathrm{C}, \mathrm{WC} / \mathrm{AC}$, and $1 \mathrm{wt} \% \mathrm{Pt} / \mathrm{AC}$ were found to be $602 \mathrm{~m}^{2} / \mathrm{g}, 655 \mathrm{~m}^{2} / \mathrm{g}, 703 \mathrm{~m}^{2} / \mathrm{g}$, $351 \mathrm{~m}^{2} / \mathrm{g}$, and $638 \mathrm{~m}^{2} / \mathrm{g}$, while the BET surface areas for WC/AC with Pt loadings ranging from 0.1 to $2.0 \mathrm{wt} \%$ were $307 \mathrm{~m}^{2} / \mathrm{g}, 298 \mathrm{~m}^{2} / \mathrm{g}, 285 \mathrm{~m}^{2} / \mathrm{g}, 273 \mathrm{~m}^{2} / \mathrm{g}$, and $270 \mathrm{~m}^{2} / \mathrm{g}$, respectively. Figure S1 depicts nitrogen adsorption/desorption isotherm and $\mathrm{DH}$ pore size distributions of the tested samples. The results in Figure S1 indicate the pore size in the samples is mainly distributed between $4-8 \mathrm{~nm}$, meaning surface area and pore volumes are mainly contributed by mesoporous structures in current work. The surface area of the WC/AC sample is smaller than that of wood-char due to etching of pore structures in the wood char by tungsten oxides during the carbothermal reduction process. This etching results in enlarged and collapsed pores and decreased pore surface area, which, in turn, decreases pore surface area and pore volume of WC/AC. For the Pt-WC/AC samples, the surface area decreased with the increase of Pt loading. The decreasing of surface area should be attributed to the blocking of the pore openings by $\mathrm{Pt}$ nanoparticles during Pt reduction and nanoparticle deposition process. Metal deposition onto porous supports usually causes a drop in the surface area, because the deposited metal nanoparticles physically block both the outer surface and the openings of pore structures [24]. 
Table 2. Surface area, pore volume and average pore diameter of raw wood-char, acid treated wood-char, wood-char- $1000{ }^{\circ} \mathrm{C}, \mathrm{WC} / \mathrm{AC}, \mathrm{Pt} / \mathrm{AC}$, and $\mathrm{Pt}-\mathrm{WC} / \mathrm{AC}$ samples.

\begin{tabular}{|c|c|c|c|}
\hline Sample & BET Surface Area $\left(\mathrm{m}^{2} / \mathrm{g}\right)$ & Pore Volume $\left(\mathrm{cm}^{3} / \mathrm{g}\right)$ & Average Pore Diameter (nm) \\
\hline Raw AC & 602 & 0.53 & 4.89 \\
\hline Acid Treated AC & 655 & 0.62 & 5.37 \\
\hline $\begin{array}{l}\text { AC Thermal Treated at } \\
\qquad 1000^{\circ} \mathrm{C}\end{array}$ & 703 & 0.73 & 7.39 \\
\hline WC/AC & 351 & 0.27 & 8.05 \\
\hline $0.1 \mathrm{wt} \% \mathrm{Pt}-W C / A C$ & 307 & 0.25 & 8.11 \\
\hline $0.2 \mathrm{wt} \% \mathrm{Pt}-\mathrm{WC} / \mathrm{AC}$ & 298 & 0.25 & 8.1 \\
\hline $0.5 \mathrm{wt} \% \mathrm{Pt}-W C / A C$ & 285 & 0.23 & 8.15 \\
\hline $1.0 \mathrm{wt} \% \mathrm{Pt}-W C / A C$ & 273 & 0.22 & 8.25 \\
\hline $2.0 \mathrm{wt} \% \mathrm{Pt}-\mathrm{WC} / \mathrm{AC}$ & 270 & 0.20 & 8.28 \\
\hline $1.0 \mathrm{wt} \% \mathrm{Pt} / \mathrm{AC}$ & 638 & 0.66 & 7.5 \\
\hline
\end{tabular}

\subsection{X-ray Diffraction (XRD)}

Figure 3 plots the XRD patterns of the calcined W/AC at $300{ }^{\circ} \mathrm{C}, \mathrm{WC} / \mathrm{AC}, 1 \mathrm{wt} \% \mathrm{Pt}-\mathrm{WC} / \mathrm{AC}$, and $5 \mathrm{wt} \% \mathrm{Pt} / \mathrm{AC}$ samples. $\mathrm{WO}_{3}$ (JCPDS no. 72-0677) was formed in the calcined W/AC at $300{ }^{\circ} \mathrm{C}$ (Figure 3-1a). Figure 3(1)b shows the XRD pattern of the prepared WC/AC sample with diffraction peaks at $2 \theta$ of $31.49,35.62,48.28,64.21,73.09$, and 77.12 and $d$ values of $2.8435,2.5165,1.8815,1.4529$, 1.2930, and 1.2355. These diffraction peaks are assigned to tungsten carbide (WC), and correspond to the lattice planes of $\left(\begin{array}{lll}0 & 0 & 1\end{array}\right),\left(\begin{array}{lll}1 & 0 & 0\end{array}\right),\left(\begin{array}{lll}1 & 0 & 1\end{array}\right),\left(\begin{array}{lll}1 & 1 & 0\end{array}\right),\left(\begin{array}{lll}1 & 1 & 1\end{array}\right)$, and $\left(\begin{array}{lll}1 & 0 & 2\end{array}\right)$. Figure 3(1)c demonstrates the XRD pattern of $1 \mathrm{wt} \% \mathrm{Pt}-\mathrm{WC} / \mathrm{AC}$ where only the diffraction peaks of WC were discovered. No obvious $\mathrm{Pt}$ diffraction peaks were observed, because the Pt content was too low to detect. X-ray diffraction patterns of $5 \mathrm{wt} \% \mathrm{Pt} / \mathrm{AC}$ are shown in Figure 3(1)d, where two weak diffraction peaks at 39.81 and 46.21 are exhibited, corresponding to the (111) and (200) planes of Pt. The Pt nanoparticle size is calculated as $7.9 \mathrm{~nm}$.

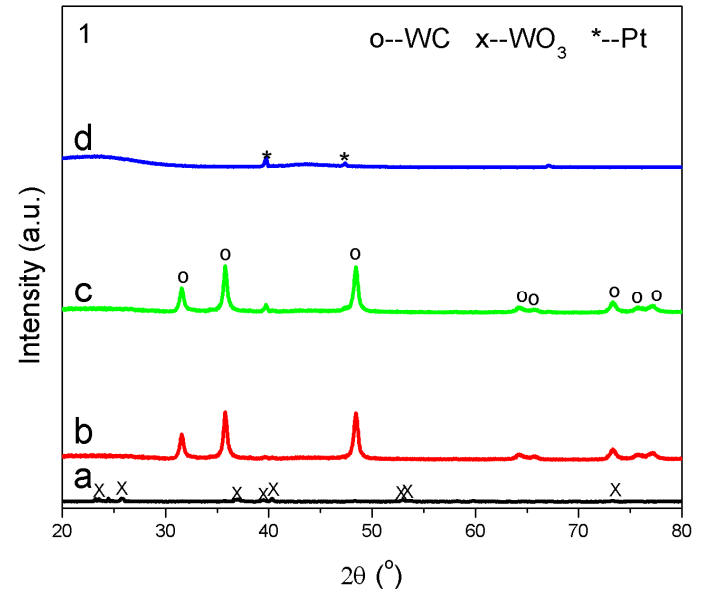

(1)

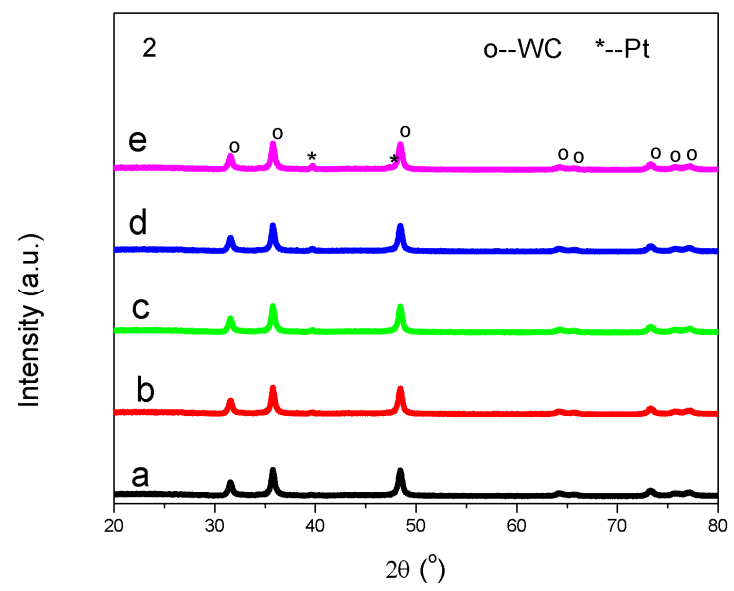

(2)

Figure 3. X-ray powder diffraction (XRD) patterns of calcined $\mathrm{W} / \mathrm{AC}$ at $300^{\circ} \mathrm{C}(\mathbf{1}-\mathrm{a}), \mathrm{WC} / \mathrm{AC}(\mathbf{1}-\mathrm{b})$, $1 \mathrm{wt} \% \mathrm{Pt}-\mathrm{WC} / \mathrm{AC}(\mathbf{1}-\mathrm{c})$ and $5 \mathrm{wt} \% \mathrm{Pt} / \mathrm{AC}(\mathbf{1}-\mathrm{d})$ samples and Pt-WC/AC sample, with different Pt loadings of $0.1 \%(2-a), 0.2 \%(2-b), 0.5 \%(2-c), 2.0 \%(2-d)$, and $5.0 \%(2-e)$.

Figure 3(2) illustrates the XRD patterns of the Pt-WC/AC samples. Similar to Figure 3(1)C $(1.0 \mathrm{wt} \% \mathrm{Pt}-\mathrm{WC} / \mathrm{AC})$, where only WC diffraction peaks were observed, no Pt diffraction peaks were measured for the $0.1,0.2,0.5$ and $2.0 \mathrm{wt} \%$ Pt-WC/AC samples. Pt peaks did not appear because of the 
small amount of Pt present. Both the Pt and WC diffraction peaks were detected in the $5 \% \mathrm{Pt}-\mathrm{WC} / \mathrm{AC}$ sample (Figure 3(2)e).

\subsection{Field Emission Scanning Electron Microscope (FESEM)}

Figure 4 shows the morphology of $\mathrm{AC}(\mathrm{a}), \mathrm{AC}-1000{ }^{\circ} \mathrm{C}(\mathrm{b}), \mathrm{WC} / \mathrm{AC}(\mathrm{c})$, and $1 \mathrm{wt} \% \mathrm{Pt}-\mathrm{WC} / \mathrm{AC}$ (d). SEM image (Figure 4a) show the morphology of the solid char of pine wood chips gasified at $800{ }^{\circ} \mathrm{C}$ under $\mathrm{CO}_{2}$ atmosphere; its porous surface is contributed by the etching process by $\mathrm{CO}_{2}$ at high temperature. The $\mathrm{AC}-1000{ }^{\circ} \mathrm{C}$ became highly porous, with more pores and channels formed in the char after being carbonized at $1000{ }^{\circ} \mathrm{C}$ (Figure 4b). Original AC structure seemed to disappear in the WC/AC sample (Figure 4c), because the AC structure was demolished by the carbothermal reduction reaction between $A C$ and tungsten oxides at high temperature [22]. The wall surface of the AC was embedded with nanoparticles ranging between 3 and $10 \mathrm{~nm}$ in diameter (Figure 4c), which, according to XRD results, means that these nanoparticles should be tungsten carbide structures. There is no significant change on surface morphology after loading $1.0 \% \mathrm{Pt}$ to the WC/AC sample (Figure $4 \mathrm{~d}$ ).

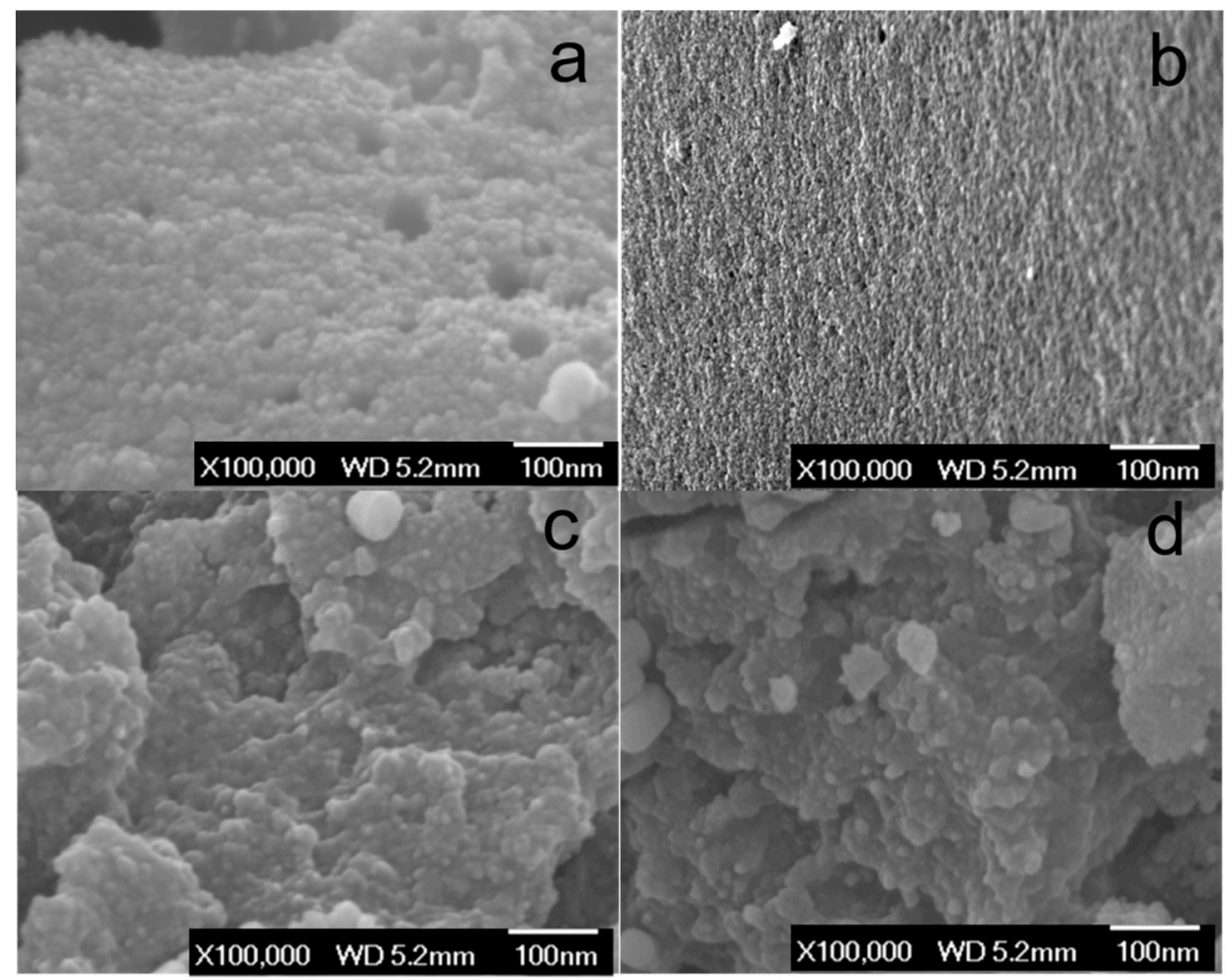

Figure 4. Field emission scanning electron microscopy (FESEM) images of wood-derived AC (a), $\mathrm{AC}-1000{ }^{\circ} \mathrm{C}(\mathbf{b}), \mathrm{WC} / \mathrm{AC}(\mathbf{c})$, and $1 \mathrm{wt} \% \mathrm{Pt}-\mathrm{WC} / \mathrm{AC}(\mathbf{d})$.

\subsection{High Resolution Transmission Electron Microscopy (HRTEM)}

Figure 5a illustrates the classic HRTEM image of the WC/AC sample. The image indicates the tungsten carbides prepared by the $C R$ method are nanoparticles averaging $8 \mathrm{~nm}$ in diameter. Figure $5 \mathrm{a}$ shows HRTEM micrographs of hexagonal WC, with the d-spacing values of $0.25 \mathrm{~nm}$ corresponding to the (100) lattice plane. Figure $5 \mathrm{~b}$ is the HRTEM image of $1 \% \mathrm{Pt} / \mathrm{AC}$, showing that the $\mathrm{Pt}$ particles deposited on AC are formed as uniform nanoparticles with particle size of about $3 \mathrm{~nm}$. The lattice planes of Pt (111) can be clearly observed. Figure 5c,d show HRTEM images of $1 \mathrm{wt} \% \mathrm{Pt}-\mathrm{WC} / \mathrm{AC}$ and $2 \mathrm{wt} \% \mathrm{Pt}-\mathrm{WC} / \mathrm{AC}$ samples, respectively. WC nanostructures have particle size of about $7-8 \mathrm{~nm}$. Smaller particles surrounding WC grains can be assigned as Pt particles. These Pt nanoparticles in $\mathrm{Pt}-\mathrm{WC} / \mathrm{AC}$ catalyst have an average size range of $2-3 \mathrm{~nm}$. Figure 5 e shows WC particles encapsulated with 3-5 layers of graphene. The outer graphene layers should be formed during the CR process, 
which can prevent the sintering or agglomeration of WC particles and promote the dispersion of WC in the AC matrix. Comparing Figure $5 b, c$, the existence of WC nanoparticles seems to promote the dispersion of Pt nanoparticles on AC.
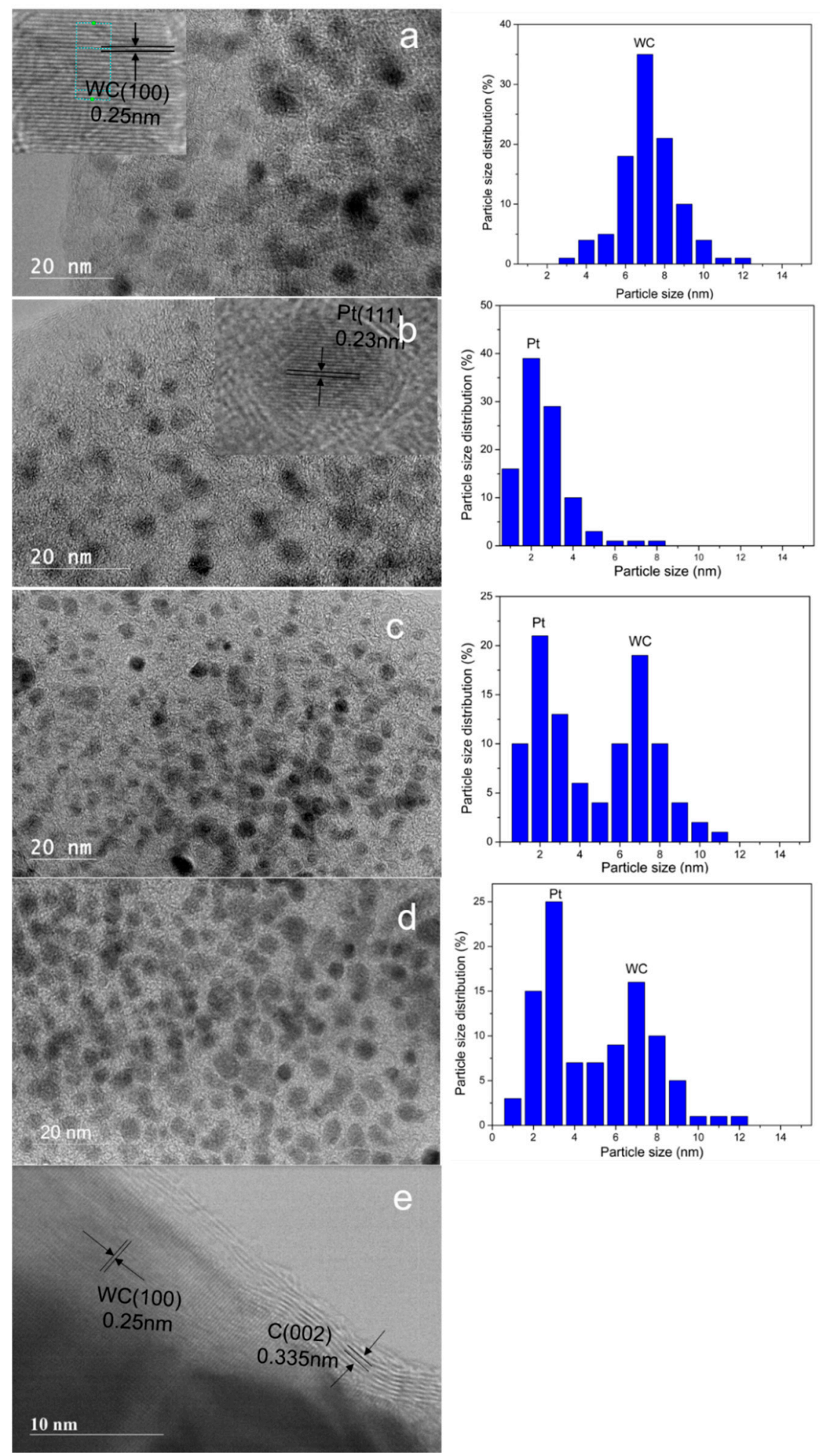

Figure 5. HRTEM images of WC/biochar (a), $1 \mathrm{wt} \% \mathrm{Pt} /$ biochar (b), $1 \mathrm{wt} \% \mathrm{Pt}-\mathrm{WC} /$ biochar $(\mathbf{c}, \mathbf{e})$ and $2 \mathrm{wt} \%$ Pt-WC/biochar (d). 
Particle size distributions were obtained by counting 200 particles selected from random regions of HRTEM vision. The distributions of $\mathrm{Pt}$ and $\mathrm{WC}$ particle sizes for WC/AC, 1\% Pt/AC, 1\% Pt-WC/AC, and $2 \% \mathrm{Pt}-\mathrm{WC} / \mathrm{AC}$ catalysts are also depicted in Figure 5. The mean size of WC particles in WC/AC is $\sim 7.2 \mathrm{~nm}$ and the mean size of Pt particles in $1 \% \mathrm{Pt} / \mathrm{AC}$ is $2.6 \mathrm{~nm}$. The mean sizes of Pt and WC particles in $1 \% \mathrm{Pt}-\mathrm{WC} / \mathrm{AC}$ is $2.2 \mathrm{~nm}$, and $7.2 \mathrm{~nm}$, respectively, while the mean sizes of $\mathrm{Pt}$ and WC particles in $2 \%$ $\mathrm{Pt}-\mathrm{WC} / \mathrm{AC}$ catalyst are $3.2 \mathrm{~nm}$ and $7.1 \mathrm{~nm}$, respectively. Pt nanoparticles on $2 \% \mathrm{Pt}-\mathrm{WC} / \mathrm{AC}$ sample seem to agglomerate a little bit compared to 1\% Pt-WC/AC sample (Figure 5d).

\subsection{CO Chemisorption}

The amounts of CO uptake by the catalyst samples were 11.2, 19.1, and $31.6 \mu \mathrm{mol} / \mathrm{g}$ for the $0.5 \%$, $1.0 \%$, and $2.0 \% \mathrm{Pt}-\mathrm{WC} / \mathrm{AC}$ samples. As a result, the dispersion of $\mathrm{Pt}$ was calculated as $43.8 \%, 37.3 \%$, and $30.8 \%$ for the $0.5 \%, 1.0 \%$, and $2.0 \% \mathrm{Pt}-\mathrm{WC} / \mathrm{AC}$ samples, respectively. The dispersion of $\mathrm{Pt}$ in $1 \% \mathrm{Pt} / \mathrm{AC}$ was also measured, and the calculated Pt dispersion was 35.3\% from the amount of CO uptake (18.1 $\mu \mathrm{mol} / \mathrm{g})$. CO chemisorption results agree with HRTEM that the presence of WC nanostructures might enhance the dispersion of Pt on AC surface.

\subsection{Test of Complete Oxidation of $\mathrm{HCHO}$}

Figure 6 shows the effluent gases (inlet gas composition: 400 ppm $\mathrm{HCHO}, 20 \% \mathrm{O}_{2}$, and Ar) analyzed by an on-line residual gas analyzer (RGA), after switching the reaction gases from the bypass flow to the catalyst bed. The reaction was carried out at room temperature with GHSV $=50,000 \mathrm{~h}^{-1}$. After switching the reaction gases from the bypass flow to the reactor loaded with the catalyst sample (1.0 $\mathrm{wt} \% \mathrm{Pt}-\mathrm{WC} / \mathrm{AC})$, the concentration of $\mathrm{HCHO}(\mathrm{m} / \mathrm{z}=30)$ decreased steadily to a low level, while intensities of the reaction products, $\mathrm{CO}_{2}$ and $\mathrm{H}_{2} \mathrm{O}$, increased gradually and reached a steady level after one hour. No CO and formate was detected in in the vent gas by RGA, which implies that $\mathrm{HCHO}$ was completely oxidized to $\mathrm{CO}_{2}$ and $\mathrm{H}_{2} \mathrm{O}$.

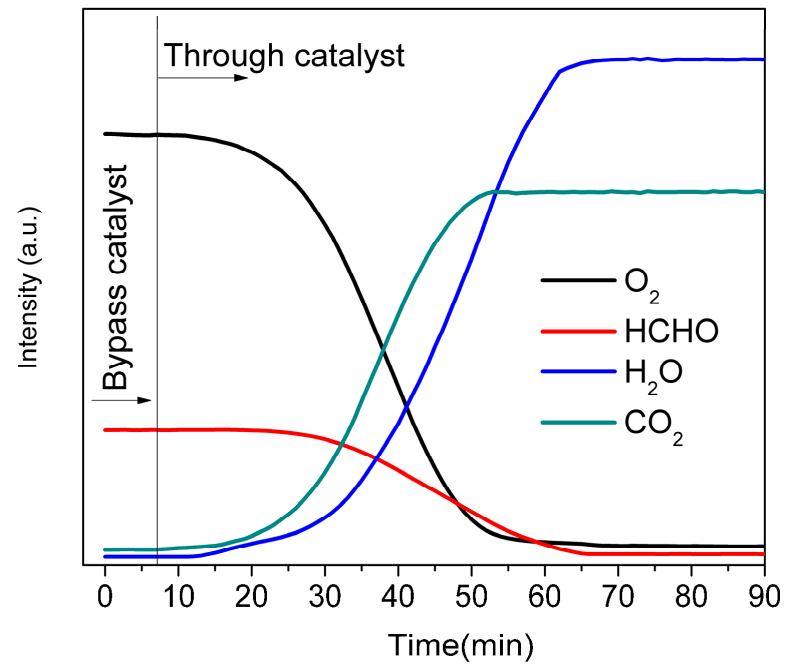

Figure 6. The effluent gases analyzed by an on-line residual gas analyzer after switching the reaction gases from the bypass flow to the reactor loaded with $1.0 \mathrm{wt} \% \mathrm{Pt}-\mathrm{WC} / \mathrm{AC}$ catalyst. Reaction conditions: formaldehyde (HCHO) $400 \mathrm{ppm}, \mathrm{O}_{2} 20 \mathrm{vol} \%$, argon balance. Total flow rate: $200 \mathrm{~mL} \cdot \mathrm{min}^{-1}$, GHSV: $50,000 \mathrm{~h}^{-1}$.

As reported in the previous works [25-31], the activity and stability of catalysts for $\mathrm{HCHO}$ oxidation is significantly influenced by experimental conditions, including reaction temperature, initial formaldehyde concentration, relative humidity $(\mathrm{RH})$, and GHSV.

The effects of reaction temperature on catalyst activity of WC/AC, Pt/AC, and Pt-WC/AC in catalytic oxidation of $\mathrm{HCHO}$ occur between 25 and $50{ }^{\circ} \mathrm{C}$. Figure 7 presents the $\mathrm{HCHO}$ conversion 
rates changing with reaction temperature over the $\mathrm{WC} / \mathrm{AC}, \mathrm{Pt} / \mathrm{AC}$, and $\mathrm{Pt}-\mathrm{WC} / \mathrm{AC}$ catalysts at a GHSV of $50,000 \mathrm{~h}^{-1}$, with the initial $\mathrm{HCHO}$ concentration of $100 \mathrm{ppm}$. As expected, the lower reaction temperature resulted in lower formaldehyde conversions. Low HCHO conversion at low temperature was noted for all the catalysts used in the process and the $\mathrm{HCHO}$ conversion rates were significantly different over various catalysts; the $\mathrm{HCHO}$ conversion rates decreased in the order of $1 \% \mathrm{Pt}-\mathrm{WC} / \mathrm{AC}>1 \% \mathrm{Pt} / \mathrm{AC}>\mathrm{WC} / \mathrm{AC}$. The 1\% Pt-WC/AC catalyst showed the highest activity at each testing temperature and reached $100 \%$ conversion rate at $45^{\circ} \mathrm{C}$. The $\mathrm{WC} / \mathrm{AC}$ sample exhibited much lower activity, and the removal of $\mathrm{HCHO}$ at low levels over pure WC/AC was mainly attributed to the adsorption by AC support [25]. With the addition of $\mathrm{Pt}$ to WC/AC, the catalytic performance was dramatically increased, due to excellent Pt activation ability toward oxygen.

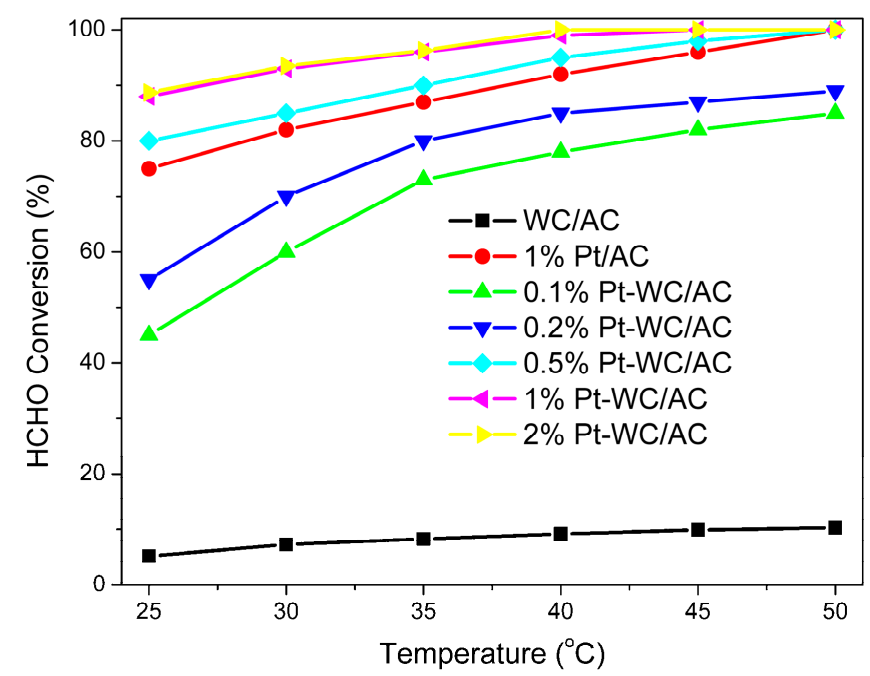

Figure 7. Effect of reaction temperature on $\mathrm{HCHO}$ conversion rates for $\mathrm{WC} / \mathrm{AC}, \mathrm{Pt} / \mathrm{AC}$, and Pt-WC/AC, with different platinum loading catalysts. Reaction conditions: $0.2 \mathrm{~g}$ catalyst was used in each run, $\mathrm{HCHO} 100 \mathrm{ppm}, \mathrm{O}_{2} 20 \mathrm{vol} \%$, argon balance, total flow rate $200 \mathrm{~mL} / \mathrm{min}$, and GHSV =50,000 $\mathrm{h}^{-1}$.

\subsubsection{Effect of Pt Loading}

The active metal loading plays a key role in the catalytic performance of supported catalysts [13]. The WC/AC samples with different Pt loading were prepared and tested for complete oxidation of $\mathrm{HCHO}$, and their activities are shown in Figure 7. The $\mathrm{HCHO}$ conversion rate over Pt-WC/AC catalysts was found to increase with increasing Pt loading in the range of $0.1-1.0 \mathrm{wt} \%$. The activity of metal catalyst usually increases with increased loading in the low content level, since the active sites in the catalyst increase with increased metal loading [31]; however, an additional increase in the metal loading may not further increase the $\mathrm{HCHO}$ conversion rate. When the metal loading surpasses a specific value, further increasing of the metal content does not increase the number of active sites due to agglomeration and sintering of metal particles, resulting in reduced catalyst stability. Peng et al. [26] found that the optimized Pt loading in $\mathrm{Pt} / \mathrm{TiO}_{2}$ was $0.6 \mathrm{wt} \%$ for complete oxidation of $\mathrm{HCHO}$ at room temperature, while Nie et al. [27] reported the ideal $\mathrm{Pt}$ loading was $1.0 \mathrm{wt} \%$ and $0.013 \mathrm{wt} \%$ in $\mathrm{Pt} / \mathrm{TiO}_{2}$ and $\mathrm{Pt} /$ honeycomb ceramics, respectively. In the current work, the catalytic performance does not noticeably change when the Pt loading reaches $2.0 \mathrm{wt} \%$; therefore, the optimal Pt loading is $1.0 \mathrm{wt} \%$ among the prepared catalysts. The calculated turnover frequencies (TOFs) for catalytic oxidation of $\mathrm{HCHO}$ at room temperature were $0.34,0.23$, and $0.13 \mathrm{~min}^{-1}$ for $0.5 \% \mathrm{Pt}-\mathrm{WC} / \mathrm{AC}$, $1 \% \mathrm{Pt}-\mathrm{WC} / \mathrm{AC}$, and $2.0 \% \mathrm{Pt}-\mathrm{WC} / \mathrm{AC}$, respectively. The TOF for $1 \% \mathrm{Pt} / \mathrm{AC}$ was calculated as $0.18 \mathrm{~min}^{-1}$. The HCHO removal rates and TOF results obtained for Pt-WC/AC catalysts indicate that the WC nanostructure promotes the catalytic removal of $\mathrm{HCHO}$ and the optimized $\mathrm{Pt}$ loading is around $1 \mathrm{wt} \%$ for the Pt-WC/AC catalysts. 


\subsubsection{Effect of Relative Humidity on Catalytic Oxidation of $\mathrm{HCHO}$}

Indoor air contains significant levels of moisture, and $\mathrm{H}_{2} \mathrm{O}$ molecules are frequently competing with reactants to adsorb on the active centers of catalysts in some gas-solid reaction cases [28,29]. It is useful to examine the impact of moisture on catalytic performance of a catalyst for complete oxidation of $\mathrm{HCHO}$ at low temperature. Previous studies have proven that the existence of certain levels of moisture can boost the complete oxidation of $\mathrm{HCHO}$ at low temperature [30,31]. Wang et al. [30] investigated the influence of moisture on the catalytic performance of $\mathrm{Mn}_{0.75} \mathrm{Co}_{2.25} \mathrm{O}_{4}$ catalyst for $\mathrm{HCHO}$ and $\mathrm{CO}$ oxidation and observed increased activity for $\mathrm{HCHO}$ oxidation with an increase of $\mathrm{RH}$, whereas $\mathrm{CO}$ oxidation activity was greatly decreased. Chen et al. [31] found the conversion rate was increased with the existence of moisture for complete oxidation of $\mathrm{HCHO}$ over $\mathrm{Au} / \mathrm{CeO} 2$ at room temperature. An et al. [32] reported that moisture had a positive effect on the formaldehyde conversion from $\sim 85 \%$ to $100 \%$ over $\mathrm{Pt} / \mathrm{Fe}_{2} \mathrm{O}_{3}-300$ catalyst at room temperature. Kwon et al. [33] investigated the effect of relative humidity on catalytic oxidation of $\mathrm{HCHO}$ over $\mathrm{Pt} / \mathrm{TiO}_{2}$ catalysts, and it was observed that moisture could enhance the complete oxidation of formaldehyde at room temperature. Zhao et al. [34] reported the enhanced effect of moisture on the ozone catalytic oxidation (OZCO) of formaldehyde over $\mathrm{MnO}_{x}$ catalysts.

The influence of moisture on the catalytic performance of $1.0 \mathrm{wt} \% \mathrm{Pt}-\mathrm{WC} / \mathrm{AC}$ catalyst for the complete oxidation of $\mathrm{HCHO}$ was investigated at $30{ }^{\circ} \mathrm{C}$, with $\mathrm{RH}$ levels of $0 \%, 20 \%, 40 \%$, and $60 \%$, and the results are plotted in Figure 8 . The 1\% Pt-WC/AC exhibits different activity and stability depending on $\mathrm{RH}$ level. In the dry stream, $\mathrm{HCHO}$ conversion increased slowly in the first $2 \mathrm{~h}$ running, then decreased gradually with time on stream (TOS); the HCHO conversion rate decreased to below $50 \%$ after $10 \mathrm{~h}$ running. For the humidified stream, the $\mathrm{HCHO}$ removal efficiency decreases in the order of $40 \%>20 \%>60 \%$. The HCHO conversion rate was significantly improved by moisture up to $50 \%$ RH. Over $91 \%$ The $\mathrm{HCHO}$ conversion rate was achieved at $40 \% \mathrm{RH}$, while only $46.7 \% \mathrm{HCHO}$ was converted at $0 \%$ humidity after $10 \mathrm{~h}$ TOS.

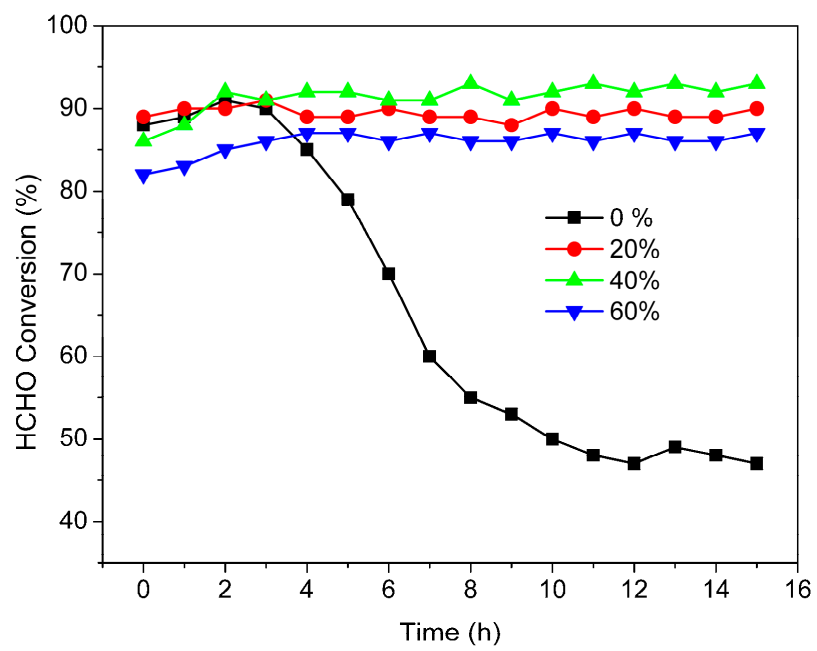

Figure 8. Effect of relative humidity $(\mathrm{RH})$ on the catalytic oxidation of $\mathrm{HCHO}$ over the $1 \% \mathrm{Pt}-\mathrm{WC} / \mathrm{AC}$ catalyst with time on stream (TOS). Reaction conditions: $0.2 \mathrm{~g}$ catalyst, temperature $=30^{\circ} \mathrm{C}, \mathrm{HCHO}$ initial concentration $=200 \mathrm{ppm}$, gas hourly space velocity $(\mathrm{GHSV})=50,000 \mathrm{~h}^{-1}$.

Three reaction models have been studied for complete oxidation of formaldehyde through the gas-solid reaction process [35-37]: (i) the Langmuir-Hinshelwood (L-H) mechanism: this reaction process assumes a surface reaction between the adsorbed $\mathrm{HCHO}$ molecules and the adsorbed oxygen on active sites of metal catalysts [38,39]; (ii) the Eley-Rideal (E-R) reaction model: this model proposes a reaction between adsorbed oxygen molecules and $\mathrm{HCHO}$ molecules from the gas phase [40]; and (iii) the Mars-Van Krevelen (MVK) reaction model: this process proposes an oxidative-reductive 
reaction of a $\mathrm{HCHO}$ molecule and oxygen on different reactive sites $[35,38,41]$. The MVK model has been extensively used to study complete oxidation of organic compounds over noble metal catalysts [42] and the mechanism has been proposed for formaldehyde oxidation over $\mathrm{Pt} / \mathrm{TiO}_{2}$ catalyst by Zhang et al. [43] using the in situ DRIFTS experiment method. HCHO in air is first adsorbed onto the Pt active sites and reacts with surface $\mathrm{OH}$ to form an intermediate dioxymethylene (DOM) [44]. $\mathrm{O}_{2}$ molecules then dissociative adsorb onto the Pt active sites and split into atomic oxygen species. Consequently, the intermediate DOM is converted to formate species, which are further oxidized to $\mathrm{CO}$ and $\mathrm{H}_{2} \mathrm{O} \cdot \mathrm{H}_{2} \mathrm{O}$ is desorbed from active sites and the adsorbed $\mathrm{CO}$ is oxidized by nearby adsorbed atomic oxygen to $\mathrm{CO}_{2}$, which is quickly desorbed from the catalyst surface and diffuses into the gaseous phase. Several previous works reported that hydroxyl groups serve an important role in maintaining the excellent performance of the catalysts for $\mathrm{HCHO}$ oxidation. Surface hydroxyls or oxygen atoms could promote the conversion of $\mathrm{HCHO}$ into formate. Adsorbed formate is consequently oxidized to $\mathrm{CO}_{2}$ and $\mathrm{H}_{2} \mathrm{O}$ by the adsorbed surface $-\mathrm{OH}$. The hydroxyl groups adsorbed on the active sites could be created from moisture or recovered by oxygen molecules. Therefore, the moisture in reactant effluent can be adsorbed onto surface active sites and create surface hydroxyl groups, which promote the oxidation of $\mathrm{HCHO}$. It is also noticed that the $1 \% \mathrm{Pt}-\mathrm{WC} / \mathrm{AC}$ catalyst demonstrates better activity than the $1 \% \mathrm{Pt} / \mathrm{AC}$ catalyst (Figure 7), which might be due to the interaction between WC and moisture. Tungsten carbide can activate water and form surface hydroxyl groups easily at low temperature, as proven by Zellner and Chen [45] on a single crystal WC surface.

\subsubsection{Effect of Gas Hourly Space Velocity (GHSV) on HCHO Conversion Rate}

In a gas-solid reaction system, the GHSV affects the catalyst performance in several ways. If the external mass transfer is the rate-determining step of a reaction process, then the conversion rate will increase with increased velocity; however, in most catalytic processes, increasing velocity means a short contact time, which will result in a lower conversion rate. Figure 9 plots $\mathrm{HCHO}$ conversion rates over the six catalysts (WC/AC, $\mathrm{Pt} / \mathrm{AC}$, and $\mathrm{Pt}-\mathrm{WC} / \mathrm{AC}$ with different platinum loading catalysts) at GHSVs of $50,000 \mathrm{~h}^{-1}, 100,000 \mathrm{~h}^{-1}$, and $200,000 \mathrm{~h}^{-1}$, by controlling the initial $\mathrm{HCHO}$ concentration to be $100 \mathrm{ppm}$ and feed gas with $50 \% \mathrm{RH}$. The $\mathrm{HCHO}$ conversion rate at room temperature decreases with increasing GHSV for all six catalyst samples. For example, the HCHO conversion decreased from $95.5 \%$ to $88.1 \%$ and $67.3 \%$, respectively, as the GHSV increased from 50,000 to 100,000 and $200,000 \mathrm{~h}^{-1}$ for $1 \mathrm{wt} \% \mathrm{Pt}-\mathrm{WC} / \mathrm{AC}$. The residence time of $\mathrm{HCHO}$ molecules decreases with increasing GHSV, so a shorter contact time between $\mathrm{HCHO}$ molecules and the active sites of the catalyst occurs and produces a low $\mathrm{HCHO}$ conversion rate. Zhang et al. [43] examined the effects of GHSV on the catalytic performance of $1 \% \mathrm{Pt} / \mathrm{TiO}_{2}$ for oxidation of $\mathrm{HCHO}$ at $20^{\circ} \mathrm{C}$ and found that $\mathrm{HCHO}$ was completely converted at a GHSV of $50,000 \mathrm{~h}^{-1}$. Li et al. [46] discovered the $2.0 \% \mathrm{Na}-\mathrm{Pd} / \mathrm{TiO}_{2}$ catalyst had high resistance to effect of space velocity, it maintained high $\mathrm{HCHO}$ conversion rate over a wide GHSV range of 80,000-190,000 $\mathrm{h}^{-1}$.

\subsubsection{Effect of Initial HCHO Concentration}

The effect of initial concentration on $\mathrm{HCHO}$ conversion rate was investigated over the $1 \% \mathrm{Pt} / \mathrm{AC}$ and $1 \% \mathrm{Pt}-\mathrm{WC} / \mathrm{AC}$ catalysts. Figure 10 shows the $\mathrm{HCHO}$ conversions with $\mathrm{HCHO}$ concentrations between $50 \mathrm{ppm}$ and $400 \mathrm{ppm}$ at $30^{\circ} \mathrm{C}$. It was observed that the removal efficiency is higher at a lower concentration level. $100 \%$ of conversion rate was achieved when the initial concentration of $\mathrm{HCHO}$ was $50 \mathrm{ppm}$, and the $\mathrm{HCHO}$ conversion rate decreased with the increase of the initial $\mathrm{HCHO}$ concentration. When $\mathrm{HCHO}$ concentration was $400 \mathrm{ppm}, \mathrm{HCHO}$ conversions were $51.2 \%$ and $65.7 \%$ for $1 \% \mathrm{Pt} / \mathrm{AC}$ and $1 \% \mathrm{Pt}-\mathrm{WC} / \mathrm{AC}$ catalysts, respectively. As reported in previous works, most of the studies were conducted under formaldehyde concentrations in the range of 100-1000 ppm [14]. Peng et al. [26] examined the effect of formaldehyde concentration at three levels: 100, 240, and $400 \mathrm{ppm}$, and the conversions were $41.5 \%, 33.1 \%$, and $22.7 \%$, respectively, over $\mathrm{Pt} / \mathrm{TiO}_{2}$ at room temperature. The results of current work agree with these previous reports $[14,26]$. 


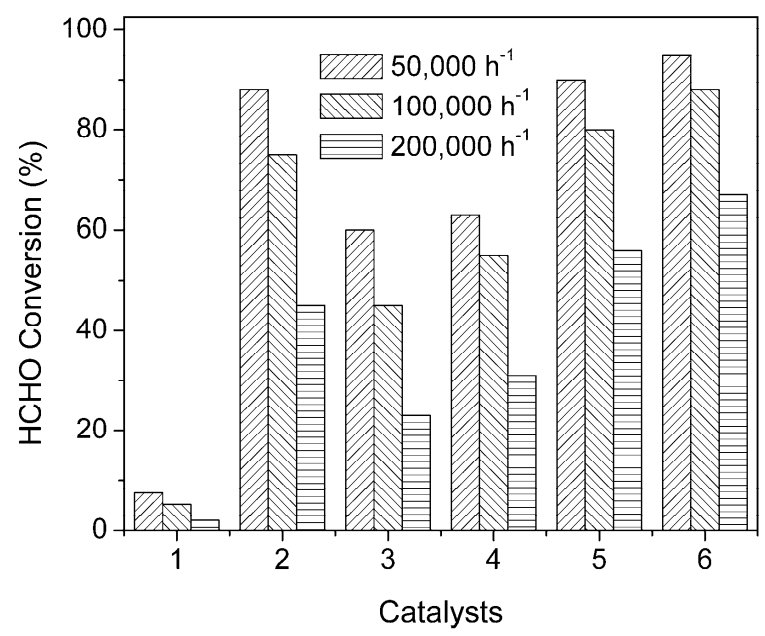

Figure 9. Removal efficiencies of $\mathrm{HCHO}$ over six catalysts: (1) WC/AC, (2) $1 \% \mathrm{Pt} / \mathrm{AC}$, (3) $0.1 \%$ $\mathrm{Pt}-\mathrm{WC} / \mathrm{AC}$, (4) $0.2 \% \mathrm{Pt}-\mathrm{WC} / \mathrm{AC}$, (5) 0.5\% Pt-WC/AC and (6) 1\% Pt-WC/AC under different space velocities. Reaction conditions: 100 ppm $\mathrm{HCHO}, 20$ vol\% $\mathrm{O}_{2}$, argon balance, $\mathrm{RH}: 50 \%$.

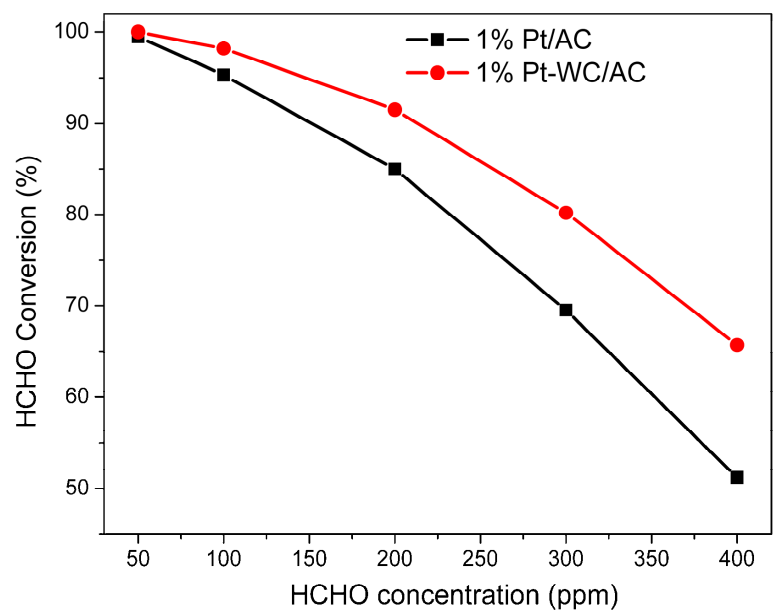

Figure 10. Effect of initial concentration of $\mathrm{HCHO}$ on the conversion rate of the $1 \% \mathrm{Pt} / \mathrm{AC}$ and $1 \% \mathrm{Pt}-\mathrm{WC} / \mathrm{AC}$ catalysts. Reaction temperature $=30{ }^{\circ} \mathrm{C}, \mathrm{O}_{2}=20.0 \mathrm{vol} \%$, argon balance, $\mathrm{GHSV}=50,000 \mathrm{~h}^{-1}$.

\subsection{Stability of $1 \%$ Pt/AC and $1 \%$ Pt-WC/AC Catalysts}

The stability of $1 \% \mathrm{Pt} / \mathrm{AC}$ and $1 \% \mathrm{Pt}-\mathrm{WC} / \mathrm{AC}$ catalysts were tested at $30{ }^{\circ} \mathrm{C}, \mathrm{GHSV}$ of $50,000 \mathrm{~h}^{-1}$ and $\mathrm{RH}$ of feed gas of $40 \%$. As shown in Figure 11, with the increase of time, the HCHO conversion rate over $1 \% \mathrm{Pt} / \mathrm{AC}$ catalyst decreased gradually from the initial value of $91.5 \%$ to $82.9 \%$ after $30 \mathrm{~h}$ running. The $1 \% \mathrm{Pt}-\mathrm{WC} / \mathrm{AC}$ catalyst was found to be relatively stable for a period of over $30 \mathrm{~h}$, with a decrease in the conversion rate from $95.5 \%$ to $94.0 \%$.

Both catalysts could be regenerated by reducing at $300{ }^{\circ} \mathrm{C}$ using $4 \% \mathrm{H}_{2}$ in argon. The conversion rates of both catalysts recovered to initial values, indicating the deactivation of the catalysts is reversible. The loss of activity may be due to adsorption of the $\mathrm{HCHO}$ oxidation intermediate $\mathrm{CO}$ over Pt active sites at low temperature [47] or the formation of $\mathrm{PtO}$ species, which could lead to a lower reaction rate of $\mathrm{HCHO}$ oxidation and cause catalyst deactivation [48]. Therefore, the deactivated catalyst could be regenerated through a simple reduction process, where $\mathrm{Pt}-\mathrm{CO}$ or $\mathrm{PtO}$ species are decomposed or reduced to $\mathrm{Pt}$ metal species at elevated temperature. 


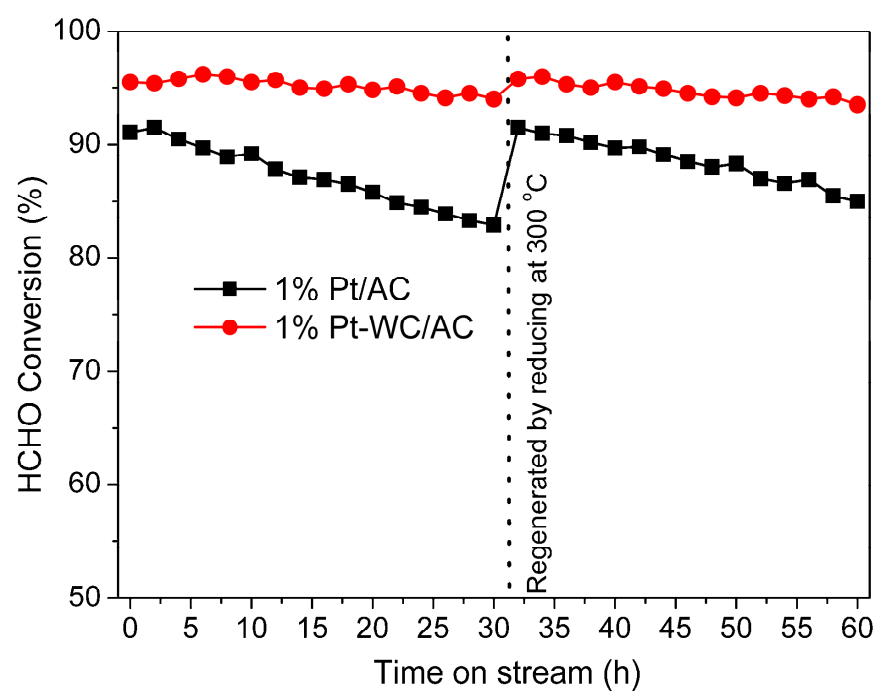

Figure 11. Stability of $1 \% \mathrm{Pt} / \mathrm{AC}$ and $1 \% \mathrm{Pt}-\mathrm{WC} / \mathrm{AC}$ catalysts at $30{ }^{\circ} \mathrm{C}, \mathrm{GHSV}$ of $50,000 \mathrm{~h}^{-1}$ and $\mathrm{RH}$ of feed gas of $40 \%$.

The activity and stability of Pt-based catalysts for $\mathrm{HCHO}$ oxidation are compared in Table 3. Pt-based catalysts have demonstrated excellent performance to the catalytic oxidation of $\mathrm{HCHO}$ at room temperature, previous studies show the $\mathrm{HCHO}$ oxidation activity and stability of Pt catalysts are reliant on their chemical and structural properties, including the $\mathrm{Pt}$ loading, particle size of $\mathrm{Pt}$, dispersion and oxidation state of $\mathrm{Pt}$, and the chemical and textural properties of the support materials [49-53]. Pt loading is an important factor that affects both the performance and the cost of the Pt-based catalyst. Pt loadings are between $0.1-2 \mathrm{wt} \%$ in most of the cases, though it could be as low as $0.08 \mathrm{wt} \%$ to efficiently convert $\mathrm{HCHO}$ at room temperature [50]. The particle size and dispersion of Pt are the key factors to affect catalytic active sites and activities of Pt-based catalysts for catalytic oxidation of HCHO [49,50]. Pt particle size can be controlled by using appropriate preparation method and support materials. Pt particle sizes are usually around 2-3 nm for Pt-based catalysts reported in the literature [52,53] and current work; for catalysts with low Pt loadings, Pt particle sizes could be manipulated to less than $1 \mathrm{~nm}[50,51]$. Pt oxidation states were observed to be related to the initial activity and long term performance of Pt-based catalysts in the oxidation of $\mathrm{HCHO}$ at low temperature [51-53], it was confirmed that metallic $\left(\mathrm{Pt}^{0}\right)$ was more active for the oxidation of $\mathrm{HCHO}$ while the existence of $\mathrm{Pt}$ oxide $(\mathrm{PtO})$ would retard the oxidation of $\mathrm{HCHO}$ at room temperature $[51,53]$. Support materials which are rich with hydroxyl groups on surface or are highly affinity to water can promote Pt activity for oxidation of $\mathrm{HCHO}$ at room temperature [53]. 
Table 3. The activity and stability of Pt-based catalysts for HCHO oxidation.

\begin{tabular}{|c|c|c|c|c|c|}
\hline Catalyst & Pt Particle Size (nm) & Reaction Conditions & HCHO Conversion (\%) & Time-on-Stream (h) & Works \\
\hline 1\% Pt-WC/AC & $2-3$ & $\begin{array}{c}0.2 \mathrm{~g} \text { catalyst, } 30^{\circ} \mathrm{C}, \mathrm{HCHO} 100 \mathrm{ppm}, \\
\mathrm{O}_{2} 20 \mathrm{vol} \% \text {, argon balance, total flow rate } \\
200 \mathrm{~mL} / \mathrm{min} \text { and GHSV }=50,000 \mathrm{~h}^{-1}\end{array}$ & $93-96$ & 60 & Current work \\
\hline $1 \% \mathrm{Pt} / \mathrm{AC}$ & 5 & $\begin{array}{c}6000 \text { ppm HCHO in air, } 40-80^{\circ} \mathrm{C}, \\
\text { GHSV }=8727 \mathrm{~h}^{-1} .\end{array}$ & $40-100$ & 2 & 49 \\
\hline $0.08 \% \mathrm{Pt} / \mathrm{TiO}_{2}$ & $<1$ & $\begin{array}{l}160 \mathrm{ppm} \mathrm{HCHO}, 20 \mathrm{vol} \% \mathrm{O}_{2} \text { with different } \\
\text { relative humidity }(\mathrm{RH}), 30{ }^{\circ} \mathrm{C} \text {, weight hourly } \\
\text { space velocity }(\mathrm{WHSV})=30,000 \mathrm{~mL} \mathrm{~h}^{-1} \mathrm{~g}_{\text {cat }}{ }^{-1}\end{array}$ & 100 & 20 & 50 \\
\hline $0.2 \% \mathrm{Pt} / \mathrm{SiO}_{2}$ & $<1$ & $\begin{array}{l}0.05 \mathrm{~g} \text { catalyst, } 11.4 \mathrm{ppm} \mathrm{HCHO} / \mathrm{N}_{2} \text { flowing at } \\
45 \mathrm{~mL} / \mathrm{min} \text { and pure } \mathrm{O}_{2} \text { flowing at } 5 \mathrm{~mL} / \mathrm{min} \text {, } \\
25-100{ }^{\circ} \mathrm{C} \text {. }\end{array}$ & Turnover frequency: $1-2$ & 60 & 51 \\
\hline $\mathrm{Pt} / \mathrm{LDO}(\mathrm{N})$ & 2.6 & $\begin{array}{c}100 \text { ppm HCHO, } 20 \% \mathrm{O}_{2} \text {, balanced by } \mathrm{N}_{2} \\
75^{\circ} \mathrm{C} \text {, space velocity }(\mathrm{SV})=6000 \mathrm{~mL} \mathrm{~g}^{-1} \mathrm{~min}^{-1}\end{array}$ & 95-100 & 60 & 52 \\
\hline $\begin{array}{c}1 \% \mathrm{Pt} / \mathrm{CeO}_{2}\left(\mathrm{Al}_{2} \mathrm{O}_{3},\right. \\
\left.\mathrm{ZrO}_{2}, \mathrm{TiO}_{2}\right)\end{array}$ & $2-3$ & $\begin{array}{c}25^{\circ} \mathrm{C}, \mathrm{HCHO} / \mathrm{H}_{2} \mathrm{O} / \mathrm{O}_{2} / \mathrm{N}_{2}=100 \mathrm{ppm} / \\
500 \mathrm{ppm} / 20 \text { vol. } \% / \text { balance } \mathrm{N}_{2} \text { with a total flow } \\
\text { rate of } 300 \mathrm{~mL} \cdot \mathrm{min}^{-1} \text {. }\end{array}$ & $20-60$ & - & 53 \\
\hline
\end{tabular}




\subsection{Possible Promotion Effects of WC to Pt Catalyst}

Two pathways have been proposed for the $\mathrm{HCHO}$ oxidation reaction. The first pathway follows three steps over Pt active sites: $\mathrm{HCHO} \rightarrow \mathrm{H}_{2} \mathrm{CO}_{2} \rightarrow \mathrm{HCO}_{2} \rightarrow \mathrm{CO}_{2}$ [54]. The mechanism involves the formate species being directly oxidized by $\mathrm{O}_{2}$ to $\mathrm{CO}_{2}$. The second pathway is $\mathrm{HCHO} \rightarrow \mathrm{CO} \rightarrow \mathrm{CO}_{2}$ [51]. In this proposed mechanism, $\mathrm{HCHO}$ first decomposes directly to $\mathrm{CO}$ over $\mathrm{Pt}$ sites, followed by $\mathrm{CO}$ oxidation by oxygen; $\mathrm{CO}$ is the essential intermediate of $\mathrm{HCHO}$ oxidation.

$\mathrm{OH}$ species play a significant role for $\mathrm{HCHO}$ oxidation over Pt-based catalysts. In the first pathway, $\mathrm{OH}$ groups on the catalysts favor $\mathrm{HCHO}$ adsorption by promoting the formation of the dioxymethylene $(\mathrm{HCOOH})$ intermediate [55]. The existence of the dioxymethylene intermediate can significantly facilitate the oxidation of $\mathrm{HCHO}$, because of its high efficiency at decomposing into $\mathrm{CO}_{2}$ and $\mathrm{H}_{2} \mathrm{O}$. In the second mechanism, the intermediate of the $\mathrm{HCHO}$ oxidation reaction is $\mathrm{CO}$, which may strongly adsorb over Pt atoms at low temperature [54]. Therefore, Pt active sites are partially occupied by adsorbed CO, making the catalyst partially deactivated. Surface hydroxyl groups are more active to oxidize adsorbed $\mathrm{CO}$ over Pt atoms than surface oxygen species [56]. Therefore, increasing nearby hydroxyl density around the $\mathrm{Pt}$ active sites will greatly enhance $\mathrm{HCHO}$ oxidation activity and improve the stability of the catalyst. It has been proven that smaller $\mathrm{Pt}$ particles accelerate activation of $\mathrm{O}_{2}$ and form more $\mathrm{OH}$ species which can oxidize formates to $\mathrm{CO}_{2}$ through a lower reaction barrier [50]. The experimental density-functional theory (DFT) calculation results prove that Pt nanoparticles indeed preferentially bond with WC to form contacting Pt-WC nanostructures in Pt-WC/AC catalysts [57]. HRTEM and $\mathrm{CO}$ chemisorption results prove the presence of WC nanostructures increases the Pt dispersion, thereby increasing the catalytic performance to $\mathrm{HCHO}$ oxidation. WC could yield more negative electronic surface properties; that is, the electron donating effect generated by WC nanostructures promotes the ability to oxidize the adsorbed CO-like species on catalysts [58]. It was reported that WC could react with moisture to produce WC-OH species and promote the oxidation of $\mathrm{CO}$ over $\mathrm{Pt}$ atoms at low temperature [59], resulting in the improved stability of Pt-WC/AC for $\mathrm{HCHO}$ oxidation.

\section{Conclusions}

Nanostructured tungsten carbide embedded in AC was produced by carbothermal reduction of tungsten-impregnated wood-char at $1000^{\circ} \mathrm{C}$ under argon atmosphere. Pt-WC/AC catalysts were then prepared utilizing WC/AC as support. The activity and the stability of Pt-WC/AC catalysts were investigated for the complete oxidation of formaldehyde at low temperature $\left(25-50^{\circ} \mathrm{C}\right)$. The $\mathrm{HCHO}$ conversion rates were significantly affected by the catalysts; catalytic activities decreased in the order of $1 \% \mathrm{Pt}-\mathrm{WC} / \mathrm{AC}>1 \% \mathrm{Pt} / \mathrm{AC}>\mathrm{WC} / \mathrm{AC}$. Catalytic activities of Pt-WC/AC were observed to increase with increase of Pt content from 0.1 to $1.0 \mathrm{wt} \%$. The catalytic performance does not change apparently when the $\mathrm{Pt}$ loading increases to $2.0 \mathrm{wt} \%$. The optimal $\mathrm{Pt}$ loading is $1.0 \mathrm{wt} \%$ among the studied catalysts.

The effects of reaction conditions on catalyst activity of Pt-WC/AC were examined. $\mathrm{HCHO}$ conversion rate increases with increasing reaction temperature. The influence of moisture on the activity and stability of $1.0 \mathrm{wt} \% \mathrm{Pt}-\mathrm{WC} / \mathrm{AC}$ catalyst for $\mathrm{HCHO}$ oxidation was investigated over different relative humidity (RH) levels of $0 \%, 20 \%, 40 \%$, and $60 \%$. Over these levels, the catalyst HCHO removal efficiency decreases in the order: $40 \%>20 \%>60 \%>0 \%$. The effects of gas hourly space velocity (GHSV) on $1 \% \mathrm{Pt}-\mathrm{WC} / \mathrm{AC}$ catalyst for complete oxidation of $\mathrm{HCHO}$ was examined at low temperature. $\mathrm{HCHO}$ was found to be completely oxidized to $\mathrm{CO}_{2}$ and $\mathrm{H}_{2} \mathrm{O}$ at a GHSV of $50,000 \mathrm{~h}^{-1}$. Effect of initial concentration of $\mathrm{HCHO}$ was compared over the $1 \% \mathrm{Pt} / \mathrm{AC}$ and $1 \% \mathrm{Pt}-\mathrm{WC} / \mathrm{AC}$ catalysts. It was observed that the removal efficiency is higher at a lower $\mathrm{HCHO}$ concentration level. The results clearly indicate that Pt-WC/AC can efficiently catalyze the removal of $\mathrm{HCHO}$ with the assistance of $\mathrm{O}_{2}$ at low temperatures.

Supplementary Materials: The following are available online at http:/www.mdpi.com/2673-4079/1/2/8/s1, Figure S1: Nitrogen adsorption/desorption isotherm and DH pore size distributions of raw AC (a), acid treated AC (b), WC/AC (c), 1\%Pt/AC (d) and 1\% Pt-WC/AC samples (e). 
Author Contributions: Writing—original draft, Q.Y.; writing—review and editing, Q.Y., Z.C.; investigation, Q.Y.; supervision, Z.C. All authors have read and agreed to the published version of the manuscript.

Funding: This work was supported by the USDA Forest Service through Grant No. 19-JV-11111124-053 and 19-JV-11111124-063.

Acknowledgments: The experiment was conducted in October-December 2019. The authors would like to acknowledge Domtar Corp., North Carolina for providing wood chips for this study. N. G. and T. K. at USDA Forest Products Laboratory provided editorial assistance.

Conflicts of Interest: The authors declare no conflict of interest.

\section{References}

1. Salthammer, T.; Mentese, S.; Marutzky, R. Formaldehyde in the Indoor Environment. Chem. Rev. 2010, 110, 2536-2572. [CrossRef]

2. Athanassiadis, B.; George, G.A.; Abbott, P.V.; Wash, L.J. A review of the effects of formaldehyde release from endodontic materials. Int. Endod. J. 2015, 48, 829-838. [CrossRef] [PubMed]

3. Hesse, W. "Phenolic Resins" in Ullmann's Encyclopedia of Industrial Chemistry; Wiley-VCH: Weinheim, Germany, 2002. [CrossRef]

4. Kim, S.; Kim, H.J. Comparison of formaldehyde emission from building finishing materials at various temperatures in under heating system; ONDOL. Indoor Air 2005, 15, 317-325. [CrossRef] [PubMed]

5. Jiang, C.J.; Li, D.D.; Zhang, P.Y.; Li, J.G.; Wang, J.; Yu, J.G. Formaldehyde and volatile organic compound (VOC) emissions from particleboard: Identification of odorous compounds and effects of heat treatment. Build. Environ. 2017, 117, 118-126. [CrossRef]

6. McLaughlin, J.K. Formaldehyde and cancer: A critical review. Int. Arch. Occup. Environ. Heath 1994, 66, 295-301. [CrossRef] [PubMed]

7. Yang, Z.; Miao, H.; Rui, Z.; Ji, H. Enhanced Formaldehyde Removal from Air Using Fully Biodegradable Chitosan Grafted $\beta$-Cyclodextrin Adsorbent with Weak Chemical Interaction. Polymers 2019, 11, 276. [CrossRef]

8. Dingle, P.; Tapsell, P.; Hu, S. Reducing Formaldehyde Exposure in Office Environments Using Plants. Bull. Environ. Contam. Toxicol. 2000, 64, 302-308. [CrossRef]

9. Huang, Y.; Ho, S.; Lu, Y.F.; Niu, R.Y.; Xu, L.F.; Cao, J.J.; Lee, S.C. Removal of indoor volatile organic compounds via photocatalytic oxidation: A short review and prospect. Molecules 2016, 21, 56. [CrossRef]

10. Thevenet, F.; Sivachandiran, L.; Guaitella, O.; Barakat, C.; Rousseau, A. Plasma-catalyst coupling for volatile organic compound removal and indoor air treatment: A review. J. Phys. D Appl. Phys. 2014, 47, 224011. [CrossRef]

11. Jiang, Z.; Chen, M.; Shi, J.; Yuan, J.; Shangguan, W. Catalysis Removal of Indoor Volatile Organic Compounds in Room Temperature: From Photocatalysis to Active Species Assistance Catalysis. Catal. Surv. Asia 2015, 19, 1-16. [CrossRef]

12. Bai, B.; Qiao, Q.; Li, J.; Hao, J. Progress in research on catalysts for catalytic oxidation of formaldehyde. Chin. J. Catal. 2016, 37, 102-122. [CrossRef]

13. Nie, L.; Yu, J.; Jaroniec, M.; Tao, F.F. Room-temperature catalytic oxidation of formaldehyde on catalysts. Catal. Sci. Technol. 2016, 6, 3649-3669. [CrossRef]

14. Pei, J.; Zhang, J.S. Critical review of catalytic oxidization and chemisorption methods for indoor formaldehyde removal. Hvac R Res. 2011, 17, 476-503.

15. Xu, Z.; Huang, G.; Yan, Z.; Wang, N.; Yue, L.; Liu, Q. Hydroxyapatite-Supported Low-Content Pt Catalysts for Efficient Removal of Formaldehyde at Room Temperature. ACS Omega 2019, 4, 21998-22007. [CrossRef]

16. Oyama, S.T. Preparation and Catalytic Properties of Transition Metal Carbides and Nitrides. Catal. Today 1992, 15, 179-200. [CrossRef]

17. Pang, J.; Sun, J.; Zheng, M.; Li, H.; Wang, Y.; Zhang, T. Transition metal carbide catalysts for biomass conversion: A review. Appl. Catal. B Environ. 2019, 254, 510-522. [CrossRef]

18. Sullivan, M.M.; Chen, C.J.; Bhan, A. Catalytic deoxygenation on transition metal carbide catalysts. Catal. Sci. Technol. 2016, 6, 602-616. [CrossRef]

19. Patt, J.; Moon, D.J.; Phillips, C.; Thompson, L.T. Molybdenum carbide catalysts for water-gas shift. Catal. Lett. 2000, 65, 193-195. [CrossRef] 
20. Ham, D.J.; Kim, Y.K.; Han, S.H.; Lee, J.S. Pt/WC as an anode catalyst for PEMFC: Activity and CO tolerance. Catal. Today 2008, 132, 117-122. [CrossRef]

21. Wang, Q.; Zhang, C.; Shi, L.; Zeng, G.; Zhang, H.; Li, S.; Wu, P.; Sun, Y. Ultralow Pt Catalyst for Formaldehyde Removal: The Determinant Role of Support. iScience 2018, 9, 487-501. [CrossRef]

22. Yan, Q.; Lu, Y.; To, F.; Li, Y.; Yu, F. Synthesis of tungsten carbide nanoparticles in wood-char matrix as a catalyst for dry reforming of methane to syngas. Catal. Sci. Technol. 2015, 5, 3270-3280. [CrossRef]

23. Elezovic, N.R.; Babic, B.M.; Ercius, P.; Radmilovic, V.R.; Vracar, L.M.; Krstajic, N.V. Synthesis and characterization Pt nanocatalysts on tungsten based supports for oxygen reduction reaction. Appl. Catal. B Environ. 2012, 125, 390-397. [CrossRef]

24. Şahin, Ö.; Saka, C. Preparation and characterization of activated carbon from acorn shell by physical activation with $\mathrm{H}_{2} \mathrm{O}-\mathrm{CO}_{2}$ in two-step pretreatment. Bioresour. Technol. 2013, 136, 163-168. [CrossRef] [PubMed]

25. Zhang, J.; Li, Y.; Zhang, Y.; Chen, M.; Wang, L.; Zhang, C.; He, H. Effect of Support on the Activity of Ag-based Catalysts for Formaldehyde Oxidation. Sci. Rep. 2015, 5, 12950. [CrossRef]

26. Peng, J.; Wang, S. Performance and characterization of supported metal catalysts for complete oxidation of formaldehyde at low temperatures. Appl. Catal. B. 2007, 73, 282-291. [CrossRef]

27. Nie, L.; Zheng, Y.; Yu, J. Efficient decomposition of formaldehyde at room temperature over Pt/honeycomb ceramics with ultra-low Pt content. Dalton Trans. 2014, 43, 12935-12942. [CrossRef] [PubMed]

28. Date, M.; Haruta, M. Moisture effect on $\mathrm{CO}$ oxidation over $\mathrm{Au} / \mathrm{TiO}_{2}$ catalyst. J. Catal. 2001, 201, $221-224$. [CrossRef]

29. Huang, Y.C.; Luo, C.H.; Yang, S.; Lin, Y.C.; Chuang, C.Y. Improved removal of indoor volatile organic compounds by activated carbon fiber filters calcined with copper oxide catalyst. Clean Soil Air Water 2010, 38, 993-997. [CrossRef]

30. Wang, Y.; Zhu, X.; Crocker, M.; Chen, B.; Shi, C. A comparative study of the catalytic oxidation of HCHO and $\mathrm{CO}$ over $\mathrm{Mn}_{0.75} \mathrm{Co}_{2.25} \mathrm{O}_{4}$ catalyst: The effect of moisture. Appl. Catal. B Environ. 2014, 160, 542-551. [CrossRef]

31. Chen, B.B.; Shi, C.; Crocker, M.; Wang, Y.; Zhu, A.M. Catalytic removal of formaldehyde at room temperature over supported gold catalysts. Appl. Catal. B 2013, 132, 245-255. [CrossRef]

32. An, N.; Yu, Q.; Gang, L.; Li, S.; Jia, M.; Zhang, W. Complete oxidation of formaldehyde at ambient temperature over supported $\mathrm{Pt} / \mathrm{Fe}_{2} \mathrm{O}_{3}$ catalysts prepared by colloid-deposition method. J. Hazard. Mater. 2011, 186, 1392-1397. [CrossRef]

33. Kwon, D.W.; Seo, P.W.; Kim, G.J.; Hong, S.C. Characteristics of the HCHO oxidation reaction over Pt/TiO catalysts at room temperature: The effect of relative humidity on catalytic activity. Appl. Catal. B Environ. 2015, 163, 436-443. [CrossRef]

34. Zhao, D.Z.; Shi, C.; Li, X.S.; Zhu, A.M.; Jang, B.W.L. Enhanced effect of water vapor on complete oxidation of formaldehyde in air with ozone over MnOx catalysts at room temperature. J. Hazard. Mater. 2012, 239, 362-369. [CrossRef] [PubMed]

35. Zhang, Y.; Xiao, Y.; Li, L.; Song, K.; Wang, X.; Wang, C.; Jian, X.; Ji, C.; Qian, P. Formaldehyde oxidation on Co-doped reduced CeO2(111): First-principles calculations. Surf. Sci. 2020, 701, 121693. [CrossRef]

36. Ordonez, S.; Bello, L.; Sastre, H.; Rosal, R.; Diez, F.V. Kinetics of the deep oxidation of benzene, toluene, n-hexane and their binary mixtures over a platinum on $\gamma$-alumina catalyst. Appl. Catal. B 2002, 38, 139-149. [CrossRef]

37. Liotta, L.F. Catalytic oxidation of volatile organic compounds on supported noble metals. Appl. Catal. B Environ. 2010, 100, 403-412. [CrossRef]

38. Wu, H.; Ma, S.; Song, W.; Hensen, E.J.M. Density Functional Theory Study of the Mechanism of Formaldehyde Oxidation on Mn-Doped Ceria. J. Phys. Chem. C 2016, 120, 3071-13077. [CrossRef]

39. Chen, L.; Song, W.; Jing, M.; Zheng, H.; Liu, J.; Zhao, Z.; Li, Z. Influence of surface termination on formaldehyde oxidation by Mn-doped ceria: A density function theory study. Mol. Catal. 2018, 448, 30-37. [CrossRef]

40. Spivey, J.J. Complete catalytic oxidation of volatile organics. Ind. Eng. Chem. Res. 1987, 26, $2165-2180$. [CrossRef]

41. Karl, T.; Zhou, C.B.; Tong, S. Kinetics and Mechanism of Catalytic Oxidation of Formaldehyde over Hydrophobic Catalysts. Ind. Eng. Chem. Res. 1994, 33, 1680-1686. 
42. Park, S.J.; Bae, I.; Nam, I.S.; Cho, B.K.; Jung, S.M.; Lee, J.H. Oxidation of formaldehyde over Pd/Beta catalyst. Chem. Eng. J. 2012, 195, 392-402. [CrossRef]

43. Zhang, C.B.; He, H.; Tanaka, K. Catalytic performance and mechanism of a Pt/TiO 2 catalyst for the oxidation of formaldehyde at room temperature. Appl. Catal. B Environ. 2006, 65, 37-43. [CrossRef]

44. He, Y.; Ji, H. In-Situ DRIFTS study on catalytic oxidation of formaldehyde over $\mathrm{Pt} / \mathrm{TiO}_{2}$ under mild conditions. Chin. J. Catal. 2010, 31, 171-175. [CrossRef]

45. Zellner, M.B.; Chen, J.G. Surface science and electrochemical studies of WC and $\mathrm{W}_{2} \mathrm{C}$ PVD films as potential electrocatalysts. Catal. Today 2005, 99, 299-307. [CrossRef]

46. Li, Y.; Zhang, C.; He, H. Significant enhancement in activity of $\mathrm{Pd} / \mathrm{TiO}_{2}$ catalyst for formaldehyde oxidation by Na addition. Catal. Today 2017, 281, 412-417. [CrossRef]

47. Sirijaruphan, A.; Goodwin, J.G.; Rice, R.W. Investigation of the initial rapid deactivation of platinum catalysts during the selective oxidation of carbon monoxide. J. Catal. 2004, 221, 288-293. [CrossRef]

48. Huang, H.B.; Leung, D.Y.C. Complete elimination of indoor formaldehyde over supported Pt catalysts with extremely low Pt content at ambient temperature. J. Catal. 2011, 280, 60-67. [CrossRef]

49. Ma, L.; Liu, C.; Guan, Q.; Li, W. Relationship between Pt particle size and catalyst activity for catalytic oxidation of ultrahigh-concentration formaldehyde. Appl. Organomet. Chem. 2019, 33, e5217. [CrossRef]

50. Sun, X.; Lin, J.; Chen, Y.; Wang, Y.; Li, L.; Miao, S.; Pan, X.; Wang, X. Unravelling platinum nanoclusters as active sites to lower the catalyst loading for formaldehyde oxidation. Commun. Chem. 2019, 2, 27. [CrossRef]

51. Wu, H.; Chen, T.; Chen, Y.; Lee, J.; Chen, C. Formaldehyde oxidation on silica-supported Pt catalysts: The influence of thermal pretreatments on particle formation and on oxidation mechanism. J. Catal. 2017, 355, 87-100. [CrossRef]

52. Lin, M.; Yu, X.; Yang, X.; Li, K.; Ge, M.; Li, J. Highly Active and Stable Interface Derived from Pt Supported on Ni/Fe Layered Double Oxides for HCHO Oxidation. Catal. Sci. Technol. 2017, 7, 1573-1580. [CrossRef]

53. Colussi, S.; Boaro, M.; De Rogatis, L.; Pappacena, A.; de Leitenburg, C.; Llorca, J.; Trovarelli, A. Room temperature oxidation of formaldehyde on Pt-based catalysts: A comparison between ceria and other supports $\left(\mathrm{TiO}_{2}, \mathrm{Al}_{2} \mathrm{O}_{3}\right.$ and $\left.\mathrm{ZrO}_{2}\right)$. Catal. Today 2015, 253, 163-171. [CrossRef]

54. Ding, J.; Yang, Y.; Liu, J.; Wang, Z. Catalytic reaction mechanism of formaldehyde oxidation by oxygen species over $\mathrm{Pt} / \mathrm{TiO}_{2}$ catalyst. Chemosphere 2020, 248, 125980. [CrossRef] [PubMed]

55. Yan, Z.X.; Xu, Z.H.; Yu, J.G.; Jaroniec, M. Enhanced formaldehyde oxidation on $\mathrm{CeO}_{2} / \mathrm{AlOOH}$-supported Pt catalyst at room temperature. Appl. Catal. B Environ. 2016, 199, 458-465. [CrossRef]

56. Liang, Y.; Chen, L.; Ma, C. Kinetics and thermodynamics of $\mathrm{H}_{2} \mathrm{O}$ dissociation and CO oxidation on the Pt/WC (0001) surface: A density functional theory study. Surf. Sci. 2017, 656, 7-16. [CrossRef]

57. Wang, R.; Xie, Y.; Shi, K.; Wang, J.; Tian, C.; Shen, P.; Fu, H. Small-sized and contacting Pt-WC nanostructures on graphene as highly efficient anode catalysts for direct methanol fuel cells. Chem. A Eur. J. 2012, 18, 7443-7451. [CrossRef]

58. Cui, G.; Shen, P.K.; Meng, H.; Zhao, J.; Wu, G. Tungsten carbide as supports for Pt electrocatalysts with improved CO tolerance in methanol oxidation. J. Power Sources 2011, 196, 6125-6130. [CrossRef]

59. Jeon, M.K.; Daimon, H.; Lee, K.R.; Nakahara, A.; Woo, S.I. CO tolerant Pt/WC methanol electro-oxidation catalyst. Electrochem. Commun. 2007, 9, 2692-2695. [CrossRef]

(C) 2020 by the authors. Licensee MDPI, Basel, Switzerland. This article is an open access article distributed under the terms and conditions of the Creative Commons Attribution (CC BY) license (http://creativecommons.org/licenses/by/4.0/). 